\title{
DO STRICTER IMMUNIZATION LAWS IMPROVE COVERAGE? EVIDENCE FROM THE REPEAL OF NON-MEDICAL EXEMPTIONS FOR SCHOOL MANDATED VACCINES
}

\author{
Chelsea J. Richwine \\ Avi Dor \\ Ali Moghtaderi \\ Working Paper 25847 \\ http://www.nber.org/papers/w25847
NATIONAL BUREAU OF ECONOMIC RESEARCH
1050 Massachusetts Avenue
Cambridge, MA 02138
May 2019

Support for this research was provided by the Robert Wood Johnson Foundation's Policies for Action program. The views expressed here do not necessarily reflect the views of the Foundation. The views expressed herein are those of the authors and do not necessarily reflect the views of the National Bureau of Economic Research.

NBER working papers are circulated for discussion and comment purposes. They have not been peer-reviewed or been subject to the review by the NBER Board of Directors that accompanies official NBER publications.

(C) 2019 by Chelsea J. Richwine, Avi Dor, and Ali Moghtaderi. All rights reserved. Short sections of text, not to exceed two paragraphs, may be quoted without explicit permission provided that full credit, including $(\odot$ notice, is given to the source. 
Do Stricter Immunization Laws Improve Coverage? Evidence from the Repeal of Non-medical Exemptions for School Mandated Vaccines

Chelsea J. Richwine, Avi Dor, and Ali Moghtaderi

NBER Working Paper No. 25847

May 2019

JEL No. I10,I12,I18

\begin{abstract}
Nonmedical exemptions are widely shown to be associated with outbreaks of vaccine-preventable disease. In response to a recent measles outbreak in 2015, California acted to increase immunization coverage by removing all nonmedical exemptions effective in 2016. Employing a unique dataset of county-level vaccination and exemption rates at Kindergarten entry, we exploit the recent policy change in California to estimate the impact of the repeal of nonmedical exemptions on immunization coverage for school-mandated vaccines. Relative to a diverse group of control states, our findings indicate that vaccination coverage increased for all required vaccines following the repeal, ranging from 2.5\% for MMR to 5\% for Polio. We also find a significant 3.4 percentage-point decline in nonmedical exemptions, accompanied by a 2.1 percentage-point increase in medical exemptions in counties that previously had high rates of nonmedical waivers. Our findings indicate that the repeal of nonmedical exemptions in California was only partially effective in improving vaccination coverage, and may have led parents to substitute between medical and nonmedical exemptions, leading to a net decline in total exemptions of just 1 percentage-point.
\end{abstract}

Chelsea J. Richwine

George Washington University

950 New Hampshire Ave NW

Washington, DC 20052

crichwine@gwu.edu

Avi Dor

Departments of Health Policy and Economics

George Washington University

2021 K street NW, Suite 800

Washington, DC 20037

and NBER

avidor@gwu.edu
Ali Moghtaderi

George Washington University

2100 Pennsylvania Ave, Suite 300

Washington, DC 20037

moghtaderi@email.gwu.edu 


\section{Introduction}

Childhood vaccination plays a prominent role in minimizing the incidence of vaccinepreventable disease (VPD) (CDC, 2015). Beyond protecting individual children from VPDs, vaccination confers a positive externality because it contains the spread of infection in the general population and contributes to herd immunity. The Centers for Disease Control and Prevention (CDC) recommends that most childhood vaccines be administered by the time a child reaches the age of twenty-four months (CDC, 2018a). To ensure widespread immunization coverage, states have enacted school immunization mandates whereby proof of vaccination is required to enroll children in school and preschool programs.

School immunization mandates have been highly effective in achieving target vaccination rates in the U.S. (Abrevaya \& Mulligan, 2011; Carpenter and Lawler, 2017; Lawler, 2017). However, all states allow some form of exemption from vaccination. Medical exemptions are granted when a specific vaccine, or vaccination in general, can be detrimental to an individual's health. All states allow for medical exemption, subject to written certification by a licensed physician. Nonmedical exemptions allow individuals to refuse vaccination based on deeply held religious or personal beliefs that preclude vaccination. Both medical and nonmedical exemptions contain further gradations, which stipulate any additional educational or documentary requirements associated with obtaining a nonmedical exemption.

While offering nonmedical exemptions preserves parents’ autonomy to make medical decisions for their children, misplaced fear over vaccine safety and side effects in recent years has given rise to "anti-vaccination" sentiment and increased utilization of nonmedical exemptions (Omer et al., 2006, 2009; Salmon et al., 2005). Vaccine skepticism is largely linked to a retracted study originally published by the Lancet in 1998 which indicated a causal 
connection between the measles-mumps-rubella (MMR) vaccine and autism (Wakefield, 1998). Despite the withdrawal and debunking of Wakefield's study ${ }^{1}$, public discourse concerning harm associated with childhood vaccination has continued to influence beliefs about the risks of immunization, possibly leading more families to claim exemptions. Nearly two decades later, a third of U.S. parents still believe that a connection between MMR and autism exists (Graves, 2015).

In recent years, rising exemption rates have led researchers to evaluate whether the availability of nonmedical exemptions lessens the impact of mandated childhood vaccines by exerting a negative influence on coverage. A concerning number of outbreaks in counties with high rates of nonmedical exemptions has garnered the attention of policymakers and the public at large. In 2015, California experienced the most severe measles outbreak in over a decade attributable to vaccine hesitancy and availability of nonmedical exemptions. The outbreak started at Disneyland in Orange County, "a hotbed of the anti-immunization movement", and ultimately infected over 110 Californians and at least 15 others in neighboring states (Barbash, 2015; Zipprich et al., 2015). Amid the recent vaccine controversy, negative public perceptions surrounding vaccination led California to tighten their requirements to prevent VPD outbreaks and ensure that immunization coverage remains high. The state responded quickly to the 2015 measles outbreak by passing Senate Bill 277 (SB 277), which repealed all nonmedical exemptions effective in July 2016, before the start of the next school year.

In this study we exploit the repeal of nonmedical exemptions in California, relative to a group of control states, using a difference-in-differences framework to explore the impact of the policy change on immunization rates for four school-mandated vaccines required for

\footnotetext{
${ }^{1}$ See Taylor et al., 1999; Omer et al., 2009; Plotkin et al., 2009 for articles debunking Wakefield’s original findings.
} 
Kindergarten entry. These include measles-mumps-rubella (MMR), diphtheria-tetanus-pertussis (DTaP), Polio (IPV), and Hepatitis B (HepB). Our dataset combines information on changes in states' exemption provisions with county-level exemption rates and vaccine-specific immunization rates for students entering Kindergarten ${ }^{2}$. Controlling for an extensive set of covariates, incidence of vaccine preventable disease, as well as county and year fixed effects, we find that the repeal of nonmedical exemptions in California caused an increase in vaccination rates for all 4 major childhood vaccines. As expected, nonmedical exemption rates fall significantly following the repeal. However, California experiences a surprising spike in medical exemptions after the policy change, relative to control states.

Following the policy change enacted under SB 277, a small body of literature has identified notable changes in vaccination and exemption rates in response to the repeal (Buttenheim et al., 2018). However, studies to date have relied on descriptive statistics and time series data from California to approximate this response. Our paper contributes to the literature on childhood immunization policy by providing causal evidence of the impact of the repeal of nonmedical exemptions on subsequent immunization coverage and exemption rates in California by employing a control group of states that were unexposed to the policy change.

The paper is organized as follows. Section 2 provides background on state immunization and exemption policies and the repeal of nonmedical exemptions in California. Section 3 describes our data collection efforts and inclusion criteria for selection into the control group. Section 4 outlines our estimation strategy for the difference-in-differences model and event study. Section 5 presents the results from the main specification of our model and additional

\footnotetext{
${ }^{2}$ We examine immunization rates for students at Kindergarten entry because the policy change in California becomes binding at the start of the school year. While immunization recommendations are provided for certain age groups, immunization mandates become effective at the start of school entry (which for most children, is Kindergarten).
} 
robustness checks. Finally, in Section 6 we discuss policy implications and public health considerations. Additional results are included in the Appendix.

\section{Background}

\subsection{Immunization Policy and School Mandates}

Unlike most healthcare decisions, immunization is subject to strict regulation because the decision to vaccinate has clear implications for protecting individual and population health. Vaccination and exemption requirements, while controversial, are vital to sustaining herd immunity (Sadaf et al., 2013) and preventing outbreaks of vaccine preventable disease (Yang and Silverman, 2015). School vaccination laws have long been used to prevent the incidence and spread of VPDs. School immunization mandates were first enacted in Massachusetts in the 1850s, and became increasingly commonplace throughout the 20th century due to their success. By the early 1970s there were evident disparities in incident rates of VPDs between states that had enacted mandates and those that had not (Malone and Hinman, 2003).

Given the demonstrated effectiveness of compulsory vaccination in improving vaccination rates (Abrevaya and Mulligan, 2011; Lawler, 2017), school-entry immunizations are now required by law in every U.S. state. School vaccination laws, in particular, are crucial to improving coverage and reducing the incidence of disease. The timing of day care and Kindergarten entry is ideal for enforcing immunization mandates because the laws target age groups predominantly affected by common VPDs, including infants less than 1 year of age and children between the ages of 1 to 4 years old (Caron-Poulin et al., 2017). School-based laws also protect children from contracting VPDs in the school environment, a common site of transmission. Moreover, school-entry laws “represent a safety net” by ensuring widespread 
coverage at the time of enrollment—regardless of socioeconomic status, race, ethnicity, or place of residence (Orenstein and Hinman, 1999).

School entry laws help prevent the incidence of disease, rather than relying solely on reactionary measures. They also serve to reduce disparities in coverage. Lastly, school laws are effective because they can take advantage of immunization resources from the school system (e.g. clinics or educational materials) to ensure widespread access and awareness of vaccination benefits (Orenstein and Hinman, 1999). As of 2018, all 50 states plus the District of Columbia require immunization against diphtheria, tetanus, pertussis, measles, mumps ${ }^{3}$, rubella, polio, and varicella for entrance into public school kindergarten ${ }^{4}$. All but two states (Montana and South Dakota) require immunization against Hepatitis B.

\subsection{Exemptions from Immunization Mandates}

While school immunization mandates are widespread and have been highly effective in achieving high rates of coverage, state laws necessarily include certain forms of exemption from vaccination. All state laws offer medical exemptions for children with genuine contraindications to immunization. Most states also offer nonmedical, religious or philosophical exemptions for parents with profound religious or personal beliefs that oppose vaccination. While medical exemptions tend to be similar across the board, there is substantial variation in the allowance of philosophical and religious exemptions among states. As of 2018, 47 states and the District of Columbia allow for some form of nonmedical exemption. All 48 states permit religious

\footnotetext{
${ }^{3}$ According to Iowa Code, Chapter 139a. 8(6) and Iowa Administrative Code, 641-7.7(139), Kindergarten entrants are only required to be immunized against measles and rubella. However, the mumps vaccine is frequently included in the measles/rubella containing vaccine.

${ }^{4}$ ProCon.org. (2016, July 8). State-by-State: Vaccinations Required for Public School Kindergarten. Retrieved from http://vaccines.procon.org/view.resource.php?resourceID $=005979$
} 
exemption, and 17 states allow for both religious and philosophical exemption. While the majority of states allowing for nonmedical waivers have done so continuously from 2007 to the present, 3 states made significant changes to their exemption regulations in recent years. Oregon added philosophical exemptions effective in the 2013-2014 school year, while Vermont removed philosophical exemptions effective in the 2016-2017 school year. California, on the other hand, was the only state to eliminate all nonmedical exemptions (both religious and philosophical). The repeal of nonmedical exemptions in California was passed in 2015, becoming effective in August 2016 (2016-2017 school year). Only two states, Mississippi and West Virginia, have never allowed for nonmedical exemption.

The language used to describe eligibility and availability of allowances clearly differentiates between medical and nonmedical exemptions. In nearly every state, physician certification is required to obtain a medical exemption. Few states accept medical exemptions signed by other types of health care workers ${ }^{5}$. However, state laws are less clear in establishing and differentiating between different types of nonmedical exemptions. For instance, religious exemptions sometimes contain language that enable parents to obtain a waiver based on personal beliefs or philosophical objections to vaccination. Only five states ${ }^{6}$ effectively prohibit the use of religious waivers for the purpose of obtaining a philosophical exemption, by requiring membership in a religious organization or denomination (Blank et al., 2013). In states without restrictive vaccine exemption laws, religious exemptions are relatively easy to feign. The vast majority of nonmedical exemption requirements do not distinguish between religious and philosophical waivers in a meaningful way. In Blank et al.'s thorough examination of the restrictiveness of nonmedical exemptions, the authors ultimately conclude the "disconnect

${ }^{5}$ https://www.nvic.org/faqs/vaccine-exemptions.aspx

${ }_{6}$ Alaska, Kansas, Oregon, South Dakota, and Iowa. 
between religious objections to immunization in the law and in practice renders legal language irrelevant in determining who can and cannot successfully exempt their children from

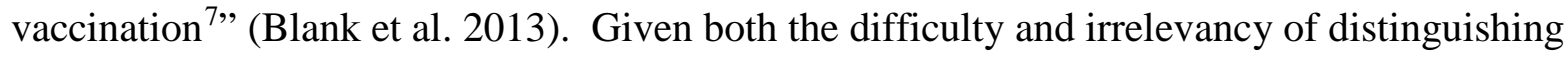
between exemption types for religious versus philosophical purposes, our analysis examines nonmedical exemptions of both types collectively. Although some states have implemented additional educational and certification requirements to obtain a nonmedical exemption (Yang \& Debold, 2014), these restrictions tend to be relatively lenient or non-binding. ${ }^{8}$

\subsection{Nonmedical Exemptions and Vaccination Coverage}

School immunization laws are put in place to mitigate the spread of infectious disease in a close group setting. However, recent studies have identified the emergence of "hotspots" or clusters of nonmedical exemptions in certain schools and counties (Olive et al., 2018). Salmon et al. (1999) and Omer et al. (2008) find evidence of geographic clustering of exemptions, and cases of measles and pertussis, respectively. Omer's analysis of geographic clustering in Michigan identified 23 statistically significant clusters of exemption rates and 6 statistically significant clusters of pertussis cases over a 10-year period. The substantial overlap between

\footnotetext{
${ }^{7}$ States' exemption policies often use inclusive language that enables parents to claim exemptions for either religious or philosophical purposes. For instance, Minnesota allows for non-medical exemption on the basis of “conscientiously held beliefs", which does not expressly include region, but certainly does not exclude it. (Source: https://www.revisor.mn.gov/statutes/cite/121A.15). In effect, Minnesota allows for both religious and personal belief exemptions. Pennsylvania, on the other hand, only defines religious exemption in their statute, yet allows for vaccine refusal on the "basis of a strong moral or ethical conviction similar to a religious belief" (Source: https://www.pacode.com/secure/data/028/chapter23/s23.84.html). Similarly, we can interpret Pennsylvania's law to permit both religious and philosophical exemption from immunization.

${ }^{8}$ Beyond establishing types of allowable exemptions for school immunization requirements, state law also stipulates the rules and requirements for obtaining a medical or nonmedical waiver. Some states have passed legislation requiring parents to receive immunization education prior to obtaining an exemption for their child, and several others passed notarization or affidavit requirements. Some states' regulations indicate that nonmedical exemptions will not be recognized (or exempt students may be excluded) in the event of an outbreak. A few states have even placed restrictions on medical exemptions by distinguishing between 'temporary' versus 'permanent' medical exemptions, or requiring recertification by a healthcare provider (CDC, 2017a).
} 
these groups suggests that clusters of exemptions put communities at increased risk of contracting a vaccine preventable disease. Other scholars have indicated that the restrictiveness of nonmedical exemption laws for school entry vaccination requirements can also have an effect on incident rates of vaccine preventable disease. Omer et al. (2006) and Yang and Debold (2014) both find evidence that easier-to-obtain exemptions are associated with increased incidence of disease. Given the widespread belief that outbreaks of disease are linked to the clustering of exemptions, it may be unsurprising that California responded to the 2015 measles outbreak by repealing their nonmedical exemptions.

In recent years, several studies have sought to uncover the impact of California's policy change on subsequent exemption rates and immunization coverage for required vaccines. Performing a spatiotemporal analysis of non-medical exemptions, Delamater et al. (2017) find a significant decline in non-medical exemptions following the repeal. Moreover, they identify a significant positive relationship between current county-level rates of medical exemptions and prior use of nonmedical exemptions in California. While preliminary findings indicate that rates of non-medical exemptions will continue to decline over time, Delamater et al. predict that the grandfather clause included in SB277 may perpetuate certain pockets of unvaccinated children for over a decade following the policy change.

Examining data from the California Department of Health, Buttenheim et al. (2018) find an overall change in the composition of immunized and exempt children in California before and after the repeal. The overall exemption rate decreased, but the decline in nonmedical exemptions was met with an increase in medical exemptions. The percentage of Kindergarten-aged students up-to-date for all required vaccines increased slightly following the policy change. 
In response to the startling rise in medical exemptions following the repeal, Mohanty et al. (2019) interviewed health officials and staff from local health jurisdictions in California to understand the reasons and circumstances surrounding the change. Ultimately they find that the lack of monitoring or review process for medical exemptions has created an opportunity for physicians and vaccine-hesitant parents to work around the recent repeal. However, none of these studies recruited a control group, and their findings draw primarily from time series data from California.

\section{Data}

\subsection{Vaccination and Exemption Rate Data}

Data for our primary outcomes were collected first-hand from state health departments as well as their immunization branch websites. In order to examine the effect of nonmedical exemptions on childhood immunization coverage, we requested school and county level immunization and exemption rates from all 50 states plus the District of Columbia (henceforth, 51 states). In particular, we asked for historical vaccine-specific immunization rates, as well as exemption rates by type (i.e. medical, religious, philosophical) through the 2017-2018 school year. Our search was confined to states that collect their own immunization data or maintain immunization registries at the school or county level. States were excluded if they relied solely on the CDC's National Immunization Survey (NIS) for immunization coverage reporting. ${ }^{9}$

For our analysis, we focus on four major vaccine combinations containing these commonly required vaccines, including: measles-mumps-rubella (MMR), diphtheria-tetanus-

\footnotetext{
${ }^{9}$ NIS reports vaccination rates for children up to the age of 23 months, which is prior to the window surrounding kindergarten entry. Moreover, it is possible for unvaccinated children in NIS to obtain vaccination in later years.
} 
pertussis (DTaP), Polio (IPV), and Hepatitis B (HepB) ${ }^{10}$. In order to compare vaccination coverage across states, we cross-referenced information on school-entry immunization mandates to account for variation in dosage requirements. All vaccine-specific rates are therefore reflective of each state's unique dosage requirements. ${ }^{11}$

After requesting immunization and exemption rates from all 51 states, we received county level data from 30 states and school level data from 21 states. ${ }^{12}$ From the information we did receive, our sample was further restricted to states that met the criteria necessary to carry out our analysis. States were retained only if they provided (1) vaccine-specific rates (e.g. \% up-todate for DTaP), (2) immunization rates at Kindergarten entry (rather than age-reported rates) ${ }^{13}$, and (3) immunization data pre- and post- 2016 (our treatment year). After applying these elimination criteria, our sample consists of 12 states with school-level data and 16 states with county-level data. Given the somewhat larger sample size and ease of comparison, we employ county-level data for our analyses.

The main specification of our model uses a balanced-panel of seven states that reported the outcome variables ${ }^{14}$ consistently from the 2012 to 2017 school year (Arizona, California,

\footnotetext{
${ }^{10}$ We also collected data on varicella immunization rates, however they were ultimately excluded from our analysis because states were inconsistent in their method of recording varicella vaccination rates. While some states solely recorded vaccinations, others accounted for immunization through both vaccination as well as physician-verified history of varicella (chickenpox).

${ }^{11}$ While MMR and Hepatitis B dosage requirements tend to be standard (2 and 3 doses required by Kindergarten entry, respectively) there is greater variation in the timing and quantity of dosage requirements for Polio and DTaP/DT. For instance, some states require 5 doses of the DTaP/DTP vaccine, whereas others will accept 3 or 4 doses as "up-to-date" depending on the age of the recipient at the time of vaccination.

${ }^{12}$ These states are not mutually exclusive. Some states report both school and county level data, whereas others report only at a single level of aggregation. We use school level data to construct county level data if the state only reports at the school-level.

${ }^{13}$ Some states provide coverage data for pre-school children aged 19 through 35 months old, the time period during which most childhood vaccines are recommended. While vaccination rates for children and infants provide a good estimate of coverage at the time of school entry, this leaves at least 2 years between the recommendation window and school entry for parents to meet all vaccination requirements. Therefore, collecting information at school entry, opposed to during the recommendation window, allows us to more accurately differentiate between delayed vaccination and vaccination refusal.

${ }^{14}$ With one exception, Kansas does not provide exemption data for the time period. Therefore, we have complete immunization data for all 7 states, and exemption data for 6 states.
} 
Connecticut, Kansas, Minnesota, Pennsylvania, and Rhode Island). As a robustness check, we include all states that meet the aforementioned three criteria, which constitute an unbalanced panel of states from the 2009 to 2017 school year. The list of states included in our study and years of available data are provided in Table 1.

Our dataset also contains county-level exemption rates for medical, religious, and philosophical (personal belief) exemptions. While we initially attempted to differentiate between rates of religious and philosophical exemption in our data collection (and did so successfully for some states), many states do not separate types of nonmedical exemptions in their records. In several cases, exemptions were reported simply as "medical” or "nonmedical”. Therefore, it was often impossible to disentangle the use of nonmedical exemptions for "religious” versus "philosophical” purposes.

For our analysis, we collapse religious and philosophical exemption rates into "nonmedical” exemptions. It is also important to note that for each type of exemption, rates reflect the percentage of Kindergarteners with an exemption for at least one vaccine. Therefore, exemption rates do not necessarily correspond with individual vaccination rates. While some children are exempt from all vaccines, others have an exemption for one type of vaccine and are up-to-date for the remaining requirements.

\subsection{Policy Variables}

In addition to county-level coverage rates, we coded state-level dummy variables to account for the policy environment in each region. We surveyed each state's immunization regulations and identified certain provisions that may limit or enhance a parent's ability to obtain a nonmedical exemption for their child. Namely, we record whether each state allows for 
nonmedical exemptions. We primarily rely on Blank et al. (2013) to identify vaccine exemption provisions in each state. We complemented this database with information from Center for Disease Control and Prevention (CDC), Conference of State Legislators, and individual state legislature databases. In a few cases, we reached out to immunization program officials in state health departments for clarification on the language used to describe exemption provisions. Similar to our difficulties in separating types of exemption rates, it is also difficult to distinguish between types of exemption regulations. Consistent with our categorization of exemption rates, we also combine religious and philosophical exemption regulations into a category for nonmedical exemptions. As a robustness check, we exclude states that disallow the use of religious exemption for philosophical purposes by restricting eligibility for nonmedical exemptions to members of religious groups. Table 1 provides details of state exemption provisions.

\subsection{Outbreak Data}

Beyond immunization rates, our data set includes incidence of vaccine preventable disease (VPD) outbreaks by state over time. We use three different measures of outbreaks. The first measure uses annual state-level incident rates for 7 different VPDs, which rely on reports from the CDC's National Notifiable Diseases Surveillance System. We account for the sum of all incident rates for available VPDs that are preventable by the required childhood vaccines included in our sample. Specifically, state level incident rates were available for measles, mumps, rubella (preventable by MMR vaccination); diphtheria, pertussis, tetanus (preventable by DTaP/DTP 
vaccination); and hepatitis $\mathrm{B}^{15}$. VPD outbreak variables are particularly important for our difference-in-differences identification strategy because outbreaks may induce parents to vaccinate their children. Additionally, outbreaks might lead states to adopt stricter exemption policies, or even disallow nonmedical exemptions altogether. Consequently, exclusion of this variable would likely lead to omitted variable bias.

Our annual VPD incident rates are recorded in the calendar year, while the school year typically begins in the month of August. Thus, VPD incidents occurring between January of each year and the school year start date might influence parental decisions to vaccinate their children. In the second measure, we use weekly VPD rates from the CDC, which enable us to track the incidence of VPDs up to the point of school entry each year. Weekly rates comprise the annual rates used in the main specification. However, they are limited to high prevalence VPDs (such as pertussis), and omit outbreaks of low frequency VPDs such as a measles, polio, and diphtheria. In an alternative specification using weekly VPD rates, incidents are recorded from August $1^{\text {st }}$ of each year through July $1^{\text {st }}$ of the subsequent year. We lag incident rates by one year to account for vaccination response to a previous year's outbreak.

Finally, following Oster (2018), we also employ data from Google Trends as a robustness check, to measure the frequency of searches related to vaccine preventable disease. We examine the effect of the repeal on vaccination coverage while controlling for disease-specific Google search rates of VPDs that can be prevented with the four vaccines explored in our paper (DTaP/DTP, Polio, MMR, and Hepatitis B). We account for the frequency of searches for the following phrases: "polio"; "measles" + "mumps" + "rubella”, "diphtheria” + "tetanus” +

\footnotetext{
${ }^{15}$ There is no outbreak data for Polio because it has been officially eliminated in the U.S. for almost 40 years. No cases have originated domestically since 1979; the last documented case was brought in from foreign travel in 1993. Source: https://www.cdc.gov/polio/us/index.html
} 
"pertussis" + "whooping cough"; "hepatitis”. All data are recorded annually from August $1^{\text {st }}$ of each year through July $1^{\text {st }}$ of the subsequent year (the year before school enrollment).

\subsection{Control Variables}

To account for the possibility that non-policy related factors may influence parents' willingness to vaccinate, we include demographic information (i.e. the percentage of the population by age group, gender, race and ethnicity), median household income, and the percentage of women older than 18 years old with a bachelor's degree or higher, from the American Community Survey. We also include unemployment rates from the Bureau of Labor Statistics.

\section{Estimation Strategy}

To estimate the effect of nonmedical exemptions on state vaccination rates, we exploit the change in California's exemption policy in 2016 using a difference-in-differences (DiD) approach. We estimate:

$Y_{c s t}=\alpha_{c}+\lambda_{t}+\beta_{1} x_{c s t}+\beta_{2}\left(\right.$ outbreak $\left._{s t-1}\right)+\beta_{3}\left(\right.$ repeal nonmedex net $\left._{s t}\right)+\varepsilon_{i s t}$

The outcome variable, $\mathrm{Y}_{\mathrm{cst}}$, is either the percentage of kindergarten-aged children who are up-todate for a specific vaccine in county $c$ in state $s$ in year $t$, or the percentage of kindergarten-aged children who used medical or nonmedical exemptions to opt out of at least one vaccination. For our analysis, our outcome is defined by the school year. Thus, vaccination and exemption rates are defined as the rates at the time of school entry in August $1^{\text {st }}$ of each year. The remaining 
variables are measured by calendar year. Our independent variable of interest, repeal of nonmedical exemptions, is a binary variable indicating exposure to the policy event. California moved to repeal nonmedical exemptions in 2015, yet the law became effective in July 2016. The treatment variable, repeal nonmedex st, equals 1 for California in the years 2016 and 2017 and 0 otherwise. Since California's policy change became effective at the start of the 2016 school year, outcome variables recorded in 2016 are part of the post-treatment period. We therefore identify the causal effect of treatment, the coefficient on repeal nonmedex ${ }_{\text {st }}$, by taking the difference in treatment and control states, before and after the intervention period marked by the start of the 2016 school year.

In addition to county-level immunization and exemption rates, our model controls for annual incidents rates of vaccine preventable disease in the previous year, as well as a vector of time-varying county and state covariates, including demographic and socio-economic characteristics. County and year fixed effects are denoted by $\alpha_{c}$ and $\lambda_{t}$, respectively. Standard errors are clustered at the county level.

While attributes of exemption policies vary across states, the inclusion of county fixed effects should account for most of the policy variation, with the exception of changes in educational requirements for three states in our sample: California, Oregon, and Washington. However, due to the timing and limited scope of the requirements, we do not expect these changes to influence our outcomes of interest. ${ }^{16}$

\footnotetext{
${ }^{16}$ In Washington State, an educational requirement was enacted in 2011 but the data for that state were only available as of 2014. California required parents to receive information on VPD risks prior to obtaining a nonmedical exemption (Silverman, 2003). However, the requirement went into effect in 2014 and soon became immaterial with the repeal of nonmedical exemptions in 2016. Moreover, the governor added a signing statement to the bill that excluded religious exemptions, which likely diminished the bill's overall impact. Oregon also passed an educational requirement in 2014. The law only requires exempting parents to complete an online educational module consisting of a short video, which allows the user to skip through segments. Given the lack of interaction with a real healthcare provider, and the ease of opportunity for any parent to avoid absorbing the information, we consider this requirement to be effectively non-binding.
} 
The main specification of our model uses a difference-in-differences design to estimate the effect of the repeal of nonmedical exemptions on subsequent immunization and exemption rates. The difference-in-differences framework relies on the parallel trends assumption that treatment and control group outcomes would have evolved in parallel, absent the policy intervention. Although the parallel trends assumption is not directly testable, we examine trends in adjusted vaccination and exemption rates in the pretreatment period (prior to the repeal of nonmedical exemptions in California) using a leads and lags model.

$$
\begin{gathered}
\left.Y_{c s t}=\alpha_{c}+\lambda_{t}+\beta_{1} x_{c s t}+\beta_{2} \text { (outbreak }_{s t-1}\right)+\sum_{\tau=1}^{4} \beta_{-\tau} \text { repeal nonmedex }_{s, t-\tau}+ \\
\sum_{\tau=0}^{1} \beta_{+\tau} \text { repeal nonmedex }_{s, t+\tau}+\varepsilon_{i s t}
\end{gathered}
$$

In this specification, repeal nonmedex $x_{s, t-\tau}$ takes the value of one $\tau$ years before the repeal in California and zero otherwise. Similarly, repeal nonmedex $x_{s, t+\tau}$ takes the value of one $\tau$ years after the repeal in California, and zero otherwise.

\section{Results}

\subsection{Summary Statistics}

Table 2 presents mean outcomes and covariates separately for California and control states for both balanced ( $N=6$ control states) and unbalanced panels ( $N=15$ control states) in the year 2015, one year before the repeal of nonmedical exemptions in California. Compared to both sets of control states, California recorded lower vaccination rates and higher nonmedical exemption rates. This suggests that prior to the repeal of nonmedical exemptions, Californians were 
relatively more hesitant to vaccinate their children. Compared to the 6 control states in our balanced sample, California recorded more incidents of VPDs.

The comparison is slightly different when we include control states from the unbalanced panel. While pertussis incidents are still more prevalent in California relative to control states, the incident rates of all other VPDs are higher in control states than in California. It is worth mentioning that California had the highest rate of pertussis, the most common VPD among all states. There were other differences, for example California was more populated, and more educated, and had higher median household income.

\subsection{Vaccination and Exemption Trends in California and Control States}

Figure 1 presents the vaccination rates and exemption rates for Kindergarten-aged children in California from 2000 to 2017. Vaccination rates were steadily decreasing in California between the years 2000 and 2013, yet increased substantially in 2014 for all major vaccines, followed by a modest increase in 2015. However, following the repeal of nonmedical exemptions, California experienced a marked increase in coverage for all required vaccines. Nonmedical exemption rates were increasing in California before the repeal and dropped sharply thereafter. Medical exemptions, on the other hand, were effectively constant during the pre-treatment period and increased substantially after the policy change.

While the increase in vaccination rates in 2014 was similar in magnitude to the increase in vaccination rates observed after the repeal of nonmedical exemptions, the 2014 spike was not accompanied by a decline in nonmedical exemption rates. Whereas, following the policy change there was a substantial drop in the nonmedical exemption rate in California. This response indicates that the increase in vaccination rates in 2014 was likely independent of the exemption 
provisions in California, and reinforces the argument that the increase in vaccination rates after 2015 was caused by the repeal of nonmedical exemptions.

Figure 2 presents vaccination and exemption rates separately for California and control states in our balanced panel between the years 2012 and 2017 without controlling for any fixed effects or covariates. Evaluating trends in vaccination rates over time, we find the increasing trend in California during the pre-policy period is not detected for control states. The vaccination rates in the control group were effectively constant throughout the sample period.

Examining trends in exemption rates in the same 6-year period, Panel B of Figure 2 exhibits a sudden drop in nonmedical exemptions in California while rates remained stable in control states. Nonmedical exemption rates were consistently higher in California compared to control states during the pre-policy period, and fall below the rates in control states after the repeal. Medical exemptions, on the other hand, were persistent in both treatment and control states prior to 2015, and the rates were similar in California and control states. Following the repeal, California experienced a sharp increase in medical exemptions while control states' exemption rates remained unchanged.

\subsection{Event Study}

We further investigate the parallel trends assumption with an event study that examines the effect of the repeal of nonmedical exemptions in California on childhood vaccination rates and exemptions. Figure 3 presents the results of our leads and lags regression of vaccination rates and exemptions in California versus control states in our balanced panel between the years 2012 and 2017. Each point represents the vaccination rate in California relative to control states, 
adjusted for covariates and fixed effects. Vertical bars show the 95\% confidence interval. The year -1 coefficient is set to zero.

Panels A through D present the leads and lags regression results for each required vaccine. From the balanced panel, we find that the adjusted MMR, DTP, and Polio vaccination rates increased between years -4 to -3 in California relative to control states, and this increase was offset by a relative decline between years -3 to -2 , followed by a sharp increase after the policy change in 2016. The estimated lead coefficients were flat, and near zero for Hep B vaccination, and increased substantially after the repeal.

Changes in medical, nonmedical, and total exemptions in California relative to other states are depicted in Panel E. Prior to the repeal, nonmedical exemptions were increasing between years -4 to -3 in California relative to control states, and declining between years -3 and -2 , while medical exemptions were evolving in parallel in California and the control states. Total exemptions exhibited a similar trend as nonmedical exemptions. Following the policy change in 2016, California faced a stark increase in medical exemptions, and a large decrease in nonmedical exemptions relative to control states. The balance between the decline in nonmedical exemptions and rise in medical exemptions is negative. Thus, the overall exemption rate fell after the repeal of nonmedical exemptions.

Taken together, the results from our event study and examination of state trends suggest that changes in vaccination and exemption rates post-repeal are not caused by differences in pretreatment trends. Our analysis provides moderate support for the parallel trends assumption, and reveals that changes in trends experienced by California are likely attributable to the repeal of nonmedical exemptions. California's vaccination rates and medical exemptions increased at an increasing rate (and nonmedical exemptions decreased at an increasing rate) following the 
repeal. Our results illustrate that control states did not experience a change in the rate of exemptions or vaccination coverage as a result of the repeal.

\subsection{Effect of Repeal of Nonmedical Exemptions on Vaccination and Exemption Rates}

Table 3 illustrates the results from our simple differences-in-differences estimation. Panel A presents results for the simple DiD. With the evidence of non-parallel trends between the treatment and control states, we added linear state-specific time trends in alternative specifications. The results from this specification are presented in Panel B of Table 3. In both specifications, Columns 1-4 demonstrate the impact of repealing nonmedical exemptions in California on county-level immunization rates for MMR, DTP, Polio, and Hep B, respectively. Columns 5-7 illustrate the effect of repealing nonmedical exemptions on medical and nonmedical exemption rates, as well as the overall exemption rate.

The first four columns of the simple DiD indicate the repeal had a positive impact on immunization rates for all four required vaccines. However, the policy change also had a significant positive impact on medical exemptions, namely a 2.1 percentage-point increase in response to the repeal of nonmedical exemptions. Note that exemption variables are defined as the percentage of children with a medical or nonmedical exemption for at least one vaccine, thus, a 2.1 percentage-point increase in the nonmedical exemption rate does not necessarily indicate a similar decline in vaccination rates for all vaccines. As expected, repealing nonmedical exemptions significantly reduced the rate of nonmedical exemptions in California (by 3.4 
percentage-points). The balance between these two effects implies a 1.3 percentage-point reduction in the overall exemption rate.

Panel B presents the DiD results with a state-specific time trend, which allows treatment and control states to follow different trends. This specification provides a check on our simple DiD identification strategy. The effect of the repeal of nonmedical exemptions on MMR vaccination rates increased substantially after the inclusion of state-specific time trends, and the effect of the repeal on Polio vaccination dropped considerably. The addition of state time trends changes the magnitude of other vaccination rate coefficients slightly, yet all estimates remain positive and statistically significant. The effect of the repeal on medical and nonmedical exemptions was largely unchanged. Our findings continue to demonstrate a simultaneous increase in medical exemptions, replacing nearly two-thirds of the reduction in nonmedical exemptions.

The second row of Panels A and B present the effect of vaccine preventable disease (VPD) outbreaks on immunization coverage and exemption rates. Our results are consistent with the findings of Oster (2018) and Schaller et al. (2017). In both specifications, outbreaks of VPDs significantly increased vaccination rates for required childhood vaccines. VPD incidents significantly increased all vaccination rates, and did not change medical or nonmedical exemption rates in specifications without state-specific time trends. After the inclusion of statespecific time trends, the coefficients for vaccination rates dropped for each vaccine and remained positive and statistically significant for all vaccines except MMR. Our results suggest that parent decisions to vaccinate are influenced by outbreaks of vaccine preventable disease. An increase in 
VPD incidents consistently leads to an increase in vaccination coverage. However, these effects pale in comparison with the effect of the repeal of nonmedical exemptions.

The change in medical and nonmedical exemption rates experienced in California counties is illustrated graphically in Figure 4. Panel A depicts the distribution of rates in 2015, before the policy change. Post-policy exemption rates in 2017 are shown in Panel B. In these figures we can see a clear decline in nonmedical exemptions accompanied by a notable increase in medical exemptions in the post-treatment period (2017). Moreover, the largest increase in medical exemptions occur in counties that used to have high rates of nonmedical exemptions. This is particularly worrisome since unvaccinated children are concentrated in certain counties where vaccination rates may drop below the level needed for herd immunity.

\section{Additional Estimates and Robustness Checks}

In this section we re-examine the impact of the repeal of nonmedical exemptions on vaccination coverage by modifying certain aspects of our base model assumptions. First, we account for variation in population size by employing our simple difference-in-differences model with population weights. Ultimately we are interested in whether differences in population affect the relationship between our variables of interest. Population weighting gives greater weight to rates in counties with large populations than those with small populations. The second row of Table 4 presents the results.

All estimates of the effect of the repeal of nonmedical exemptions on vaccination coverage are positive and statistically significant. Estimates are similar in magnitude to our findings from the main specification, with the exception of estimates for Polio vaccination. The estimated coefficient for Polio dropped considerably in the weighted regression. The coefficient 
on nonmedical exemption is notably smaller than estimates produced in other specifications. This is perhaps reflective of the fact that some of the smaller counties in Northern California experienced the largest decline in nonmedical exemption rates. In weighted regressions, the decrease in nonmedical exemptions is similar in magnitude to estimates of the increase in medical exemption, leaving the overall exemption rate unchanged.

As a second robustness check, we re-examine the impact of the repeal on vaccination and exemption rates by employing weekly incident rates for a select set of VPDs. Unlike annual rates, the weekly rates account for low frequency diseases, such as measles. Findings are presented in the third row of Table 4. Our results are robust to the inclusion of weekly VPD information and the omission of low frequency VPDs. These findings suggest that vaccination and exemption response is largely driven by high-frequency VPDs, rather than less common infectious diseases. Interestingly, the coefficient on MMR vaccination is virtually unchanged by the omission of measles incidents from the model.

While our baseline model includes CDC outbreak data, our third robustness check uses Google Trends data as an alternative measure capturing public awareness of infectious disease. CDC data is a more precise measure of verified cases of VPD outbreaks in each state, whereas Google Trends data may provide a better approximation for public concern for different VPDs over time. Similar to incident rates, Google searches for VPDs capture the frequency of outbreaks, but also reflect general concern for different VPDs and changes in search interest over time that might affect decisions to vaccinate (Oster, 2018). Theoretically, we expect a higher number of Google searches for disease in the periods following an outbreak. Therefore, we employ search rates from the previous year to account for delayed vaccination response to search 
interest in VPDs. To assess the linear relationship between the CDC incident rates and Google trends search rate measures, Pearson's correlation coefficients are provided in the Appendix.

The fourth row of Table 4 presents the results of our difference-in-differences estimation controlling for lagged Google search rates of VPDs. The estimated coefficients for MMR and DTP vaccination drop considerably and are no longer statistically significant. Coefficients for Polio and Hep B vaccination, on the other hand, remain statistically significant at the $1 \%$ level and only slightly lower than the point estimates from our main specification. The effect of the repeal on medical and nonmedical exemptions is also similar to the effects we found while controlling for CDC outbreak data in our primary model. Controlling for Google trends data, the repeal reduces nonmedical exemptions by almost 3.7 percentage-points and increases medical exemptions by 2 percentage-points. All coefficients are statistically significant at the $1 \%$ level.

For our fourth robustness check, we examine the effect of the repeal on vaccine coverage using all states that satisfy our inclusion criteria. Since some states did not have data for all counties in every year, this results in an unbalanced panel of 16 states from 2009 to 2017. Estimating the impact of the repeal with a larger unbalanced panel has the advantage of yielding more precise estimates of the effect of the policy change. However, since fewer states have available data in earlier years, the definition of the control group changes during the pretreatment period as we get further away from the policy change. These results are presented in the fifth and the sixth rows of Table 4. Point estimates are generally larger than the results from the balanced sample, and they are robust to the inclusion of state-specific time trends. Event analysis graphs for the unbalanced panel demonstrate clear evidence of a post-treatment increase in vaccination rates in California relative to control states. Nonmedical exemption rates drop, 
while medical exemption rates increase, consistent with our findings from the balanced sample (results are provided in the Appendix).

As a final robustness check, we exclude states from our sample that clearly prohibit the use of religious waivers for the purpose of obtaining a philosophical exemption (i.e. Kansas, South Dakota, and Oregon). Following the analysis of Blank et al. (2013), our balanced panel omits states that limit religious exemptions to individuals who adhere to a "religion/religious doctrine/denomination" or claim membership within a "church or denomination" that is “opposed to vaccination”. Thus, we exclude Kansas from our balanced panel; in addition, we exclude South Dakota, and Oregon from our unbalanced panel. Rows 7 and 8 of Table 4 present the results of our difference-in-differences estimation for our balanced and unbalanced of states, respectively. In the balanced panel (without Kansas), the estimated coefficients are notably smaller relative to the main specification, yet remain positive and statistically significant for each required vaccine. However, the resulting coefficients in the unbalanced sample (without Kansas, South Dakota, and Oregon) are mixed. The coefficients for Polio and DTP are slightly smaller than those obtained from the full balanced panel in row 5; whereas the coefficients on MMR and Hep B are slightly larger. Overall, results indicate that the repeal of non-medical exemptions increased vaccination coverage for all vaccines, with and without the inclusion of states with strict exemption regulations.

\section{Discussion}

Our results have important public health and policy implications. Our analysis of the impact of the repeal indicates that California's policy change reduced the rate of nonmedical exemptions by more than 3 percentage-points and significantly improved vaccination coverage 
by roughly $2.5 \%$ to $5 \%$. Outbreaks of vaccine preventable disease also led to increases in vaccine coverage. However, those effects were small compared to the impact of the repeal of nonmedical exemptions, suggesting opportunities for direct policy intervention. Our findings also suggest that the policy change may have had the unintended effect of inducing parents to substitute nonmedical exemptions with medical exemptions. We find a significant 2 percentage-point increase in medical exemptions in several of our analyses, which limits the overall decline in total exemptions to just 1 percentage-point.

Given that medical exemptions are reserved for children with genuine contraindications to vaccines, the mechanism through which parents obtain medical waivers is unclear. One possibility is that medical exemptions were underutilized prior to the repeal due to the ease of obtaining nonmedical exemptions. This may have led to an increase in genuine medical exemptions as parents sought medical waivers in place of easier-to-obtain nonmedical exemptions. Another potential mechanism for the increase in medical exemptions is the new language used to guide medical exemption allowances under the law. ACIP changed their best practices guidelines for medical exemptions to reflect both contraindications as well as precautions to vaccination. The new definition expands precaution to include "any condition that might confuse diagnostic accuracy” as well as relevant family medical history (CDC, 2018b). California's repeal adopted this language in their legislation ${ }^{17}$, which may have had the effect of granting physicians broader discretion in providing medical waivers.

A more concerning possibility for the rise in medical exemptions could be related to parents seeking out physicians who are willing to exercise their discretion to grant medical exemptions to children who are generally ineligible for medical waivers. Consistent with this

${ }_{17}$ SB 277, 2015-2016 Leg, Reg Sess (Ca 2015) 
account, our analysis reveals that the largest increases in medical exemptions occurred in counties that had high rates of nonmedical exemptions prior to the repeal (see Figure 4). Moreover, exemption rates before and after the policy change remain geographically clustered in certain counties. Therefore, even if part of the increase in medical exemptions is explained by movement among those with genuine contraindications, the concentration of medical exemptions in certain areas suggests that parents may be finding illegitimate ways of obtaining medical waivers for their children.

\section{Policy Implications}

The potential to substitute between exemption types limits both the short-term and longrun benefits of the repeal. Our findings reveal that immediately following the policy change, the magnitude of the increase in medical exemptions accounted for nearly two-thirds of the decline in nonmedical exemptions. The evidence suggesting that parents can successfully obtain medical exemptions in place of nonmedical exemptions has major policy implications for the state of California and other states looking to tighten their immunization policies.

Policymakers and public health professionals may need to consider strategies to enhance monitoring of physician allowances of medical exemption waivers. Similar action, such as the monitoring of physician prescribing practices, has been undertaken in recent years in response to the opioid epidemic (CDC, 2017b). Immunization departments could consider a similar review process to help ensure that medical exemptions are being approved for genuine contraindications. Overall, our research findings underscore important policy considerations for the design and implementation of state vaccination laws in the future. 


\section{Public Health Implications}

Beyond fostering compliance, tightening the requirements around medical waivers will also aid in promoting public policies that protect public health. Our results indicate an inverse relationship between the availability of nonmedical exemptions and rates of immunization coverage. Moreover, "hotspots" with a large concentration of exemptions may be prone to future outbreaks of vaccine-preventable disease. Recent outbreaks from California and Washington State have demonstrated the risks of maintaining low levels of immunization coverage in counties and schools. The observed clustering of both medical and non-medical exemptions in certain California counties following the repeal suggest that certain areas remain disproportionately susceptible to future outbreaks of disease.

\section{Conclusion}

In summary, our findings suggest that the removal of nonmedical exemptions in California was initially effective in increasing vaccination rates, but the substitution between exemption types may render the repeal partially ineffective in improving immunization coverage and preventing VPDs over time. As a result, the availability and concentration of exemptions from vaccination increases the vulnerability of certain regions to outbreaks of disease. A better understanding of the response to California's repeal of nonmedical exemptions serves to inform future vaccination policies aimed at enhancing immunization coverage. Follow-up research should be directed towards identifying the mechanisms facilitating the rise in medical exemptions in California, and towards confirming the relationship between exemptions from vaccination (both medical and nonmedical) and outbreaks of vaccine preventable disease. 


\section{References}

Abrevaya, J., \& Mulligan, K. (2011). Effectiveness of state-level vaccination mandates: evidence from the varicella vaccine. Journal of Health Economics, 30(5), 966-976.

Barbash, Fred. (2015, January 22). Disneyland measles outbreak strikes in anti-vaccination hotbed of California. The Washington Post. Retrieved from https://www.washingtonpost.com.

Blank, N. R., Caplan, A. L., \& Constable, C. (2013). Exempting schoolchildren from immunizations: states with few barriers had highest rates of nonmedical exemptions. Health Affairs, 32(7), 1282-1290.

Buttenheim, A. M., Jones, M., Mckown, C., Salmon, D., \& Omer, S. B. (2018). Conditional admission, religious exemption type, and nonmedical vaccine exemptions in California before and after a state policy change. Vaccine, 36(26), 3789-3793.

Caron-Poulin, L., Rotondo, J., Cutler, J., Desai, S., \& Squires, S. (2017). Burden and deaths associated with vaccine preventable diseases in Canada, 2010-2014. Online Journal of Public Health Informatics, 9(1).

Carpenter, C. S., \& Lawler, E. C. (2017). Direct and Spillover Effects of Middle School Vaccination Requirements (No. w23107). National Bureau of Economic Research.

Center for Disease Control and Prevention (2015). State School Immunization Requirements and Vaccine Exemption Laws. Available at: https://www.cdc.gov/phlp/docs/school-vaccinations.pdf

Center for Disease Control and Prevention (2017a). State School and Childcare Vaccination Laws. Available at: https://www.cdc.gov/phlp/publications/topic/vaccinations.html

Center for Disease Control and Prevention (2017b). What States Need to Know About PDMPs. Available at: https://www.cdc.gov/drugoverdose/pdmp/states.html

Center for Disease Control and Prevention (2018a). Recommended Immunizations for Children and Adolescents Aged 18 Years or Younger, United States, 2018. Retrieved September 9, 2018 from https://www.cdc.gov/vaccines/schedules/hcp/imz/child-adolescent.html

Center for Disease Control and Prevention (2018b). Contraindications and Precautions. Available at: https://www.cdc.gov/vaccines/hcp/acip-recs/general-recs/contraindications.html

Delamater, P. L., Leslie, T. F., \& Yang, Y. T. (2017). Change in medical exemptions from immunization in California after elimination of personal belief exemptions. Journal of the American Medical Association, 318(9), 863-864.

Graves, C. (2015, February 20). Why debunking myths about vaccines hasn’t convinced dubious parents. Harvard Business Review. Retrieved from https://hbr. Org 
Iowa Department of Public Health (2018). Immunization Requirements. Retrieved September 17, 2018 from https://idph.iowa.gov/Portals/1/userfiles/39/Imm\%20Law\%20Table\%20One\%20Page\%201-2717\%20Final.pdf

Lawler, E. C. (2017). Effectiveness of vaccination recommendations versus mandates: evidence from the hepatitis A vaccine. Journal of Health Economics, 52, 45-62.

Malone, K. M., \& Hinman, A. R. (2003). Vaccination mandates: the public health imperative and individual rights. Law in Public Health Practice, 262-84.

Mohanty, S. and Rubenstein Reiss, D. (2019) Measles Outbreak Prompts States to Consider Stricter Immunization Laws. Penn Leonard Davis Institute of Health Economics. Health Policy\$ense. Retrieved from: https://ldi.upenn.edu/healthpolicysense/measles-outbreakprompts-states-consider-stricter-immunization-laws

Olive, J. K., Hotez, P. J., Damania, A., \& Nolan, M. S. (2018). The state of the antivaccine movement in the United States: A focused examination of nonmedical exemptions in states and counties. PLoS medicine, 15(6), e1002578.

Omer, S. B., Pan, W. K., Halsey, N. A., Stokley, S., Moulton, L. H., Navar, A. M., ... \& Salmon, D. A. (2006). Nonmedical exemptions to school immunization requirements: secular trends and association of state policies with pertussis incidence. Journal of the American Medical Association, 296(14), 1757-1763.

Omer, S. B., Enger, K. S., Moulton, L. H., Halsey, N. A., Stokley, S., \& Salmon, D. A. (2008). Geographic clustering of nonmedical exemptions to school immunization requirements and associations with geographic clustering of pertussis. American Journal of Epidemiology, 168(12), 1389-1396.

Omer, SB, Salmon, DA, Orenstein, W. A., deHart, M. P., \& Halsey, N. (2009). Vaccine refusal, mandatory immunization, and the risks of vaccine-preventable diseases. The New England Journal of Medicine, 360(19), 1981-8. http://dx.doi.org/10.1056/NEJMsa0806477

Orenstein, W. A., \& Hinman, A. R. (1999). The immunization system in the United States-the role of school immunization laws. Vaccine, 17, S19-S24.

Oster, E. (2018). Does disease cause vaccination? Disease outbreaks and vaccination response. Journal of Health Economics, 57, 90-101.

Plotkin, S., Gerber, J. S., \& Offit, P. A. (2009). Vaccines and autism: a tale of shifting hypotheses. Clinical Infectious Diseases, 48(4), 456-461.

Sadaf, A., Richards, J. L., Glanz, J., Salmon, D. A., \& Omer, S. B. (2013). A systematic review of interventions for reducing parental vaccine refusal and vaccine hesitancy. Vaccine, 31(40), 4293-4304. 
Salmon, D. A., Moulton, L. H., Omer, S. B., Patricia deHart, M., Stokley, S., \& Halsey, N. A. (2005). Factors associated with refusal of childhood vaccines among parents of school-aged children: a case-control study. Archives of Pediatrics \& Adolescent Medicine, 159(5), 470-476.

Salmon, D. A., Haber, M., Gangarosa, E. J., Phillips, L., Smith, N. J., \& Chen, R. T. (1999). Health consequences of religious and philosophical exemptions from immunization laws: individual and societal risk of measles. Journal of the American Medical Association, 282(1), 4753.

Schaller, J., Schulkind, L., \& Shapiro, T. M. (2017). The Effects of Perceived Disease Risk and Access Costs on Infant Immunization (No. w23923). National Bureau of Economic Research.

Silverman, R. D. (2003). No More Kidding Around: Restructuring Nonmedical Childhood Immunization Exemptions to Ensure Public Health Protection. Annals Health L., 12, 277.

Taylor, B., Miller, E., Farrington, C., Petropoulos, M. C., Favot-Mayaud, I., Li, J., \& Waight, P. A. (1999). Autism and measles, mumps, and rubella vaccine: no epidemiological evidence for a causal association. The Lancet, 353(9169), 2026-2029.

Wakefield, A. J., Murch, S. H., Anthony, A., Linnell, J., Casson, D. M., Malik, M., ... \& Valentine, A. (1998). RETRACTED: Ileal-lymphoid-nodular hyperplasia, non-specific colitis, and pervasive developmental disorder in children.

Yang, Y. T., \& Silverman, R. D. (2015). Legislative prescriptions for controlling nonmedical vaccine exemptions. Journal of the American Medical Association, 313(3), 247-248.

Yang, Y. T., \& Debold, V. (2014). A longitudinal analysis of the effect of nonmedical exemption law and vaccine uptake on vaccine-targeted disease rates. American Journal of Public Health, 104(2), 371-37

Zipprich, J., Winter, K., Hacker, J., Xia, D., Watt, J., and Harriman, K. (2015). Measles Outbreak California, December 2014-February 2015. Morbidity and Mortality Weekly Report (MMWR), 64(06); 153-154. 
Table 1: State Exemption Regulations

\begin{tabular}{|c|c|c|c|c|c|c|c|}
\hline State & ME & $\mathbf{R E}$ & PE & Education & Notarization & $\begin{array}{l}\text { Included } \\
\text { in Study? }\end{array}$ & Years \\
\hline Alabama & Yes & Yes & No & No & No & No & \\
\hline Alaska & Yes & Yes & No & No & Yes & No & \\
\hline Arizona & Yes & Yes & Yes & $\begin{array}{l}\text { No ('17) } \\
\text { Yes ('18-) }\end{array}$ & No & Yes & 2010-2017 \\
\hline Arkansas & Yes & Yes & Yes & Yes & Yes & No & \\
\hline California & Yes & $\begin{array}{l}\text { Yes ('07-'16) } \\
\text { No ('16-) }\end{array}$ & $\begin{array}{l}\text { Yes ('07-'16) } \\
\text { No ('16-) }\end{array}$ & $\begin{array}{l}\text { No ('07-'11) } \\
\text { Yes ('14) } \\
\text { No ('16) }\end{array}$ & No & Yes & $2000-2017$ \\
\hline Colorado & Yes & Yes & Yes & No & No & No & \\
\hline Connecticut & Yes & Yes & No & No & Yes & Yes & 2012-2017 \\
\hline Delaware & Yes & Yes & No & No & Yes & No & \\
\hline DC & Yes & Yes & No & No & No & No & \\
\hline Florida & Yes & Yes & No & No & No & No & \\
\hline Georgia & Yes & Yes & No & No & Yes & No & \\
\hline Hawaii & Yes & Yes & No & No & No & No & \\
\hline Idaho & Yes & Yes & Yes & No & No & No & \\
\hline Illinois & Yes & Yes & No & $\begin{array}{l}\text { No ('07-'14) } \\
\text { Yes ('15-) }\end{array}$ & No & No & \\
\hline Indiana & Yes & Yes & No & No & No & No & \\
\hline Iowa & Yes & Yes & No & No & Yes & No & \\
\hline Kansas & Yes & Yes & No & No & No & Yes & 2009-2017 \\
\hline Kentucky & Yes & Yes & No & No & Yes & No & \\
\hline Louisiana & Yes & Yes & Yes & No & No & No & \\
\hline Maine & Yes & Yes & Yes & No & No & Yes & 2014-2017 \\
\hline Maryland & Yes & Yes & No & No & No & Yes & 2014-2017 \\
\hline Massachusetts & Yes & Yes & No & No & No & Yes & 2013-2017 \\
\hline Michigan & Yes & Yes & Yes & $\begin{array}{l}\text { No ('14), } \\
\text { Yes ('15-) }\end{array}$ & No & No & \\
\hline Minnesota & Yes & Yes & Yes & No & Yes & Yes & 2012-2017 \\
\hline Mississippi & Yes & No & No & No & No & No & \\
\hline Missouri & Yes & Yes & No & No & No & No & \\
\hline Montana & Yes & Yes & No & No & Yes & No & \\
\hline Nebraska & Yes & Yes & No & No & Yes & No & \\
\hline Nevada & Yes & Yes & No & No & No & No & \\
\hline $\begin{array}{l}\text { New } \\
\text { Hampshire }\end{array}$ & Yes & Yes & No & No & Yes & No & \\
\hline New Jersey & Yes & Yes & No & No & $\begin{array}{l}\text { Yes ('07) } \\
\text { No ('08-) }\end{array}$ & No & \\
\hline New Mexico & Yes & Yes & No & No & Yes & No & \\
\hline New York & Yes & Yes & No & No & No & No & \\
\hline
\end{tabular}




\begin{tabular}{|c|c|c|c|c|c|c|c|}
\hline State & ME & $\mathbf{R E}$ & $\mathbf{P E}$ & Education & Notarization & $\begin{array}{l}\text { Included } \\
\text { in Study? }\end{array}$ & Years \\
\hline $\begin{array}{l}\text { North } \\
\text { Carolina }\end{array}$ & Yes & Yes & No & No & No & No & \\
\hline North Dakota & Yes & Yes & Yes & No & No & Yes & $2015-2017$ \\
\hline Ohio & Yes & Yes & Yes & No & No & Yes & 2014-2017 \\
\hline Oklahoma & Yes & Yes & Yes & No & No & No & \\
\hline Oregon & Yes & Yes & $\begin{array}{l}\text { No ('07-'13) } \\
\text { Yes ('13-) }\end{array}$ & $\begin{array}{l}\text { No ('07-'13) } \\
\text { Yes ('14-) }\end{array}$ & No & Yes & 2013-2017 \\
\hline Pennsylvania & Yes & Yes & Yes & No & No & Yes & $2007-2017$ \\
\hline Rhode Island & Yes & Yes & No & No & No & Yes & $2012-2017$ \\
\hline $\begin{array}{l}\text { South } \\
\text { Carolina }\end{array}$ & Yes & Yes & No & No & Yes & No & \\
\hline South Dakota & Yes & Yes & No & No & No & Yes & 2014-2016 \\
\hline Tennessee & Yes & Yes & No & No & No & No & \\
\hline Texas & Yes & Yes & Yes & No & Yes & Yes & 2015-2017 \\
\hline Utah & Yes & Yes & Yes & $\begin{array}{l}\text { No until July } \\
\text { '18 }\end{array}$ & No & No & \\
\hline Vermont & Yes & Yes & $\begin{array}{l}\text { Yes ('07-'16) } \\
\text { No ('16-) }\end{array}$ & $\begin{array}{l}\text { No ('07-'11) } \\
\text { Yes ('12-) }\end{array}$ & No & No & \\
\hline Virginia & Yes & Yes & No & No & Yes & No & \\
\hline Washington & Yes & Yes & Yes & $\begin{array}{l}\text { No ('07-'10) } \\
\text { Yes ('11-) }\end{array}$ & No & Yes & 2014-2017 \\
\hline West Virginia & Yes & No & No & No & No & No & \\
\hline Wisconsin & Yes & Yes & Yes & No & No & No & \\
\hline Wyoming & Yes & Yes & No & No & Yes & No & \\
\hline
\end{tabular}

Notes: State exemption policies, and their attributes. "ME" indicates medical exemption, "RE" indicates religious exemption, and "PE" indicates philosophical exemptions. "Education" indicates educational requirement for nonmedical exemption, and "Notarization" indicates notarization requirement for nonmedical exemption. 
Table 2: Summary Statistics

\begin{tabular}{|c|c|c|c|c|c|}
\hline & \multirow{2}{*}{$\begin{array}{l}\text { Treatment } \\
\text { California }\end{array}$} & \multicolumn{4}{|c|}{ Control States } \\
\hline & & $\begin{array}{c}\text { Balanced } \\
\text { Sample } \\
\left(\mathrm{N}_{\mathrm{s}}=6\right)\end{array}$ & & $\begin{array}{c}\text { Unbalanced } \\
\text { Sample } \\
\left(\mathrm{N}_{\mathrm{s}}=15\right)\end{array}$ & \\
\hline VARIABLES & Mean & Mean & T-stat & Mean & T-stat \\
\hline \multicolumn{6}{|l|}{ Vaccination ( \% up-to-date) } \\
\hline & $N_{c}=57$ & $\mathrm{~N}_{\mathrm{C}}=280$ & & $\mathrm{~N}_{\mathrm{C}}=817$ & \\
\hline DTP & 91.08 & 92.68 & $1.65 *$ & 93.92 & $3.21 * * *$ \\
\hline Polio & 91.55 & 93.47 & $2.06 * *$ & 94.25 & $3.03 * * *$ \\
\hline MMR & 91.36 & 92.43 & 1.11 & 93.94 & $2.87 * * *$ \\
\hline Hep B & 92.71 & 96.98 & $9.09 * * *$ & 96.61 & $5.91 * * *$ \\
\hline \multicolumn{6}{|l|}{ Exemption \%: } \\
\hline & $\mathrm{N}_{\mathrm{c}}=57$ & $\mathrm{~N}_{\mathrm{c}}=182$ & & $\mathrm{~N}_{\mathrm{C}}=434$ & \\
\hline Medical exemption & 0.26 & 0.23 & 0.66 & 0.33 & 0.92 \\
\hline Nonmedical exemption & 5.39 & 2.36 & $7.27 * * *$ & 2.82 & $5.94 * * *$ \\
\hline Total Exemption & 5.65 & 2.58 & $7.18 * * *$ & 3.15 & $5.53 * * *$ \\
\hline \multicolumn{6}{|l|}{ Demographics: } \\
\hline & $\mathrm{N}_{\mathrm{C}}=57$ & $\mathrm{~N}_{\mathrm{c}}=280$ & & $\mathrm{~N}_{\mathrm{c}}=817$ & \\
\hline$\%$ of population age 0 to 24 & 31.96 & 31.42 & 0.82 & 32.11 & 0.22 \\
\hline$\%$ of population age 25 to 34 & 13.08 & 11.37 & $5.83^{* * *}$ & 11.75 & $4.42 * * *$ \\
\hline$\%$ of population age 35 to 44 & 11.98 & 10.98 & $5.45 * * *$ & 11.25 & $3.73 * * *$ \\
\hline$\%$ of population age 45 to 54 & 12.95 & 13.07 & 0.60 & 12.94 & 0.09 \\
\hline$\%$ of population age 55 to 64 & 13.63 & 14.33 & $2.33 * *$ & 13.92 & 0.94 \\
\hline$\%$ of population age $65+$ & 16.41 & 18.83 & $3.91 * * *$ & 18.05 & $2.53 * * *$ \\
\hline$\%$ of population black & 4.32 & 3.43 & 1.38 & 5.0 & 0.74 \\
\hline$\%$ of population white & 83.68 & 92.75 & $7.09 * * *$ & 90.52 & $4.46 * * *$ \\
\hline$\%$ of population Hispanic & 30.43 & 7.74 & $12.7^{* * *}$ & 14.57 & $6.09 * * *$ \\
\hline$\%$ of population male & 50.45 & 50.12 & 1.30 & 50.27 & 0.62 \\
\hline$\%$ of female population with college degree & 24.13 & 21.66 & $2.30 * *$ & 20.63 & $3.31 * * *$ \\
\hline Population (in millions) & 0.68 & 0.12 & $5.82 * * *$ & 0.12 & $8.43 * * *$ \\
\hline \% Unemployed & 7.50 & 4.83 & $8.69 * * *$ & 4.92 & $9.99 * * *$ \\
\hline Median HH Income (in thousand) & 57.77 & 52.45 & $3.17 * * *$ & 51.66 & $3.69 * * *$ \\
\hline \multicolumn{6}{|c|}{ Outbreaks of Vaccine-Preventable (cases per 1,000,000 population): } \\
\hline Measles incidents & 2.36 & 1.93 & 1.50 & 5.22 & $2.16^{* *}$ \\
\hline Mumps incidents & 0.95 & 1.96 & $5.35 * * *$ & 6.12 & $2.70 * * *$ \\
\hline Rubella incidents & 0.05 & 0.02 & $7.35 * * *$ & 0.01 & $15.7 * * *$ \\
\hline Diphtheria incidents & 0 & 0 & - & 0.01 & $2.62 * * *$ \\
\hline Tetanus incidents & 0.10 & 0.15 & $2.32 * *$ & 0.13 & 1.51 \\
\hline Pertussis incidents & 223.7 & 128.0 & $15.2 * * *$ & 114.3 & $14.6 * * *$ \\
\hline Hepatitis B incidents & 2.82 & 3.83 & $7.14^{* * *}$ & 5.47 & $5.54 * * *$ \\
\hline Total VPD incidents & 230.0 & 135.9 & $14.8^{* * *}$ & 131.3 & $11.4^{* * *}$ \\
\hline
\end{tabular}

State and county $\mathrm{N}$ are denoted by $\mathrm{N}_{\mathrm{s}}$ and $\mathrm{N}_{\mathrm{c}}$, respectively. *, **, *** indicate statistical significant at the $10 \%, 5 \%$, and $1 \%$ level. Covariates are reported in the 2015 calendar year. Rates are weighted by county population. 


\section{Table 3: Difference-in-differences: Effect of the Repeal of Nonmedical Exemptions on Childhood Vaccination Rates and Exemptions}

\begin{tabular}{|c|c|c|c|c|c|c|c|}
\hline VARIABLES & $\begin{array}{c}(1) \\
\% \mathrm{MMR}\end{array}$ & $\begin{array}{c}(2) \\
\% \text { DTP }\end{array}$ & $\begin{array}{c}\text { (3) } \\
\text { \% Polio }\end{array}$ & $\begin{array}{c}\text { (4) } \\
\text { \% Нер B }\end{array}$ & $\begin{array}{c}\text { (5) } \\
\text { \% Nonmedical } \\
\text { exemption }\end{array}$ & $\begin{array}{c}\text { (6) } \\
\text { \% Medical } \\
\text { exemption }\end{array}$ & $\begin{array}{c}(7) \\
\text { \% Total } \\
\text { exemption }\end{array}$ \\
\hline \multicolumn{8}{|l|}{ Panel A- Simple DiD } \\
\hline Repeal of nonmedical exemptions & $\begin{array}{c}2.30^{* * *} \\
(0.86)\end{array}$ & $\begin{array}{c}2.75^{* * *} \\
(0.76)\end{array}$ & $\begin{array}{c}4.58^{* * *} \\
(0.75)\end{array}$ & $\begin{array}{l}2.31^{* * *} \\
(0.50)\end{array}$ & $\begin{array}{c}-3.42^{* * *} \\
(0.56)\end{array}$ & $\begin{array}{c}2.08^{* * *} \\
(0.13)\end{array}$ & $\begin{array}{c}-1.343^{* *} \\
(0.534)\end{array}$ \\
\hline VPD rates & $\begin{array}{c}0.24 * * * \\
(0.07)\end{array}$ & $\begin{array}{c}0.60^{* * *} \\
(0.07)\end{array}$ & $\begin{array}{c}0.50 * * * \\
(0.07)\end{array}$ & $\begin{array}{c}0.18^{* * *} \\
(0.04)\end{array}$ & $\begin{array}{l}-0.01 \\
(0.03)\end{array}$ & $\begin{array}{l}-0.00 \\
(0.01)\end{array}$ & $\begin{array}{l}-0.01 \\
(0.03)\end{array}$ \\
\hline $\begin{array}{l}\text { Observations } \\
\text { R-squared }\end{array}$ & $\begin{array}{l}2,004 \\
0.559\end{array}$ & $\begin{array}{l}2,004 \\
0.584\end{array}$ & $\begin{array}{l}2,004 \\
0.619\end{array}$ & $\begin{array}{l}2,004 \\
0.655\end{array}$ & $\begin{array}{l}1,432 \\
0.767\end{array}$ & $\begin{array}{l}1,432 \\
0.747\end{array}$ & $\begin{array}{l}1,432 \\
0.782\end{array}$ \\
\hline \multicolumn{8}{|c|}{ Panel B- Simple DiD with State-Specific Time Trends } \\
\hline Repeal of nonmedical exemptions & $\begin{array}{c}3.98^{* * *} \\
(0.79)\end{array}$ & $\begin{array}{c}2.85^{* * *} \\
(0.77)\end{array}$ & $\begin{array}{c}2.95 * * * \\
(0.75)\end{array}$ & $\begin{array}{c}2.77^{* * *} \\
(0.52)\end{array}$ & $\begin{array}{c}-3.01^{* * *} \\
(0.59)\end{array}$ & $\begin{array}{c}2.03^{* * *} \\
(0.14)\end{array}$ & $\begin{array}{l}-1.054 * \\
(0.574)\end{array}$ \\
\hline VPD rates & $\begin{array}{c}0.11 \\
(0.07)\end{array}$ & $\begin{array}{c}0.38^{* * *} \\
(0.06)\end{array}$ & $\begin{array}{c}0.31^{* * *} \\
(0.06)\end{array}$ & $\begin{array}{c}0.12^{* * *} \\
(0.04)\end{array}$ & $\begin{array}{l}-0.01 \\
(0.03)\end{array}$ & $\begin{array}{l}-0.00 \\
(0.01)\end{array}$ & $\begin{array}{l}-0.01 \\
(0.03)\end{array}$ \\
\hline Observations & 2,004 & 2,004 & 2,004 & 2,004 & 1,432 & 1,432 & 1,432 \\
\hline R-squared & 0.577 & 0.604 & 0.632 & 0.667 & 0.768 & 0.748 & 0.783 \\
\hline
\end{tabular}

Panel A: Difference-in-differences estimates of the effect of repeal of nonmedical exemptions on childhood vaccination rates and vaccination exemptions. Regressions include county and year fixed effects, county socio-economics time varying characteristics, and number of vaccine preventable disease cases per 1,000,000 population in the previous year. Standard errors are clustered at the county level. Covariate coefficients are presented in the Appendix. *, **, *** indicates statistical significance at the 10\%, 5\%, and 1\% level.

Panel B: Similar to Panel A, but also includes state-specific time trends 
Table 4: Additional Estimates and Robustness Checks

\begin{tabular}{|c|c|c|c|c|c|c|c|}
\hline VARIABLES & $\begin{array}{c}\text { (1) } \\
\text { \% MMR }\end{array}$ & $\begin{array}{c}(2) \\
\text { \% DTP }\end{array}$ & $\begin{array}{c}\text { (3) } \\
\text { \% Polio }\end{array}$ & $\begin{array}{c}\text { (4) } \\
\text { \% Нер B }\end{array}$ & $\begin{array}{c}(5) \\
\% \text { Nonmedical } \\
\text { exemption }\end{array}$ & $\begin{array}{c}(6) \\
\text { \% Medical } \\
\text { exemption }\end{array}$ & $\begin{array}{c}(7) \\
\text { \% Total } \\
\text { exemption }\end{array}$ \\
\hline Main Specification & $\begin{array}{c}2.30 * * * \\
(0.86)\end{array}$ & $\begin{array}{c}2.75 * * * \\
(0.76)\end{array}$ & $\begin{array}{c}4.58^{* * *} \\
(0.75)\end{array}$ & $\begin{array}{c}2.31 * * * \\
(0.50)\end{array}$ & $\begin{array}{c}-3.42 * * * \\
(0.56)\end{array}$ & $\begin{array}{c}2.08^{* * *} \\
(0.13)\end{array}$ & $\begin{array}{c}-1.343^{* *} \\
(0.534)\end{array}$ \\
\hline $\begin{array}{l}\text { With population weights } \\
\text { (balanced panel) }\end{array}$ & $\begin{array}{c}2.17^{* * *} \\
(0.68) \\
\end{array}$ & $\begin{array}{c}2.23^{* * *} \\
(0.59) \\
\end{array}$ & $\begin{array}{c}2.74 * * * \\
(0.49) \\
\end{array}$ & $\begin{array}{c}1.40^{* * *} \\
(0.35) \\
\end{array}$ & $\begin{array}{c}-1.65 * * * \\
(0.30) \\
\end{array}$ & $\begin{array}{c}1.64 * * * \\
(0.10)\end{array}$ & $\begin{array}{l}-0.004 \\
(0.282) \\
\end{array}$ \\
\hline $\begin{array}{l}\text { With weekly outbreak data } \\
\text { (balanced panel) }\end{array}$ & $\begin{array}{c}2.31^{* * *} \\
(0.87)\end{array}$ & $\begin{array}{c}2.72^{* * *} \\
(0.76)\end{array}$ & $\begin{array}{c}4.54^{* * *} \\
(0.75)\end{array}$ & $\begin{array}{c}2.26 * * * \\
(0.50)\end{array}$ & $\begin{array}{c}-3.42 * * * \\
(0.56)\end{array}$ & $\begin{array}{c}2.08^{* * *} \\
(0.13)\end{array}$ & $\begin{array}{c}-1.33^{* *} \\
(0.53)\end{array}$ \\
\hline $\begin{array}{l}\text { With Google trends (balanced } \\
\text { panel) }\end{array}$ & $\begin{array}{l}1.05 \\
(1.07)\end{array}$ & $\begin{array}{l}1.36 \\
(0.86)\end{array}$ & $\begin{array}{c}4.00^{* * *} \\
(0.82)\end{array}$ & $\begin{array}{c}2.00 * * * \\
(0.54)\end{array}$ & $\begin{array}{c}-3.68 * * * \\
(0.56)\end{array}$ & $\begin{array}{c}2.00^{* * *} \\
(0.13)\end{array}$ & $\begin{array}{c}-1.680 * * * \\
(0.534)\end{array}$ \\
\hline Unbalanced Panel & $\begin{array}{c}3.11^{* * *} \\
(0.73)\end{array}$ & $\begin{array}{c}3.51^{* * * *} \\
(0.69)\end{array}$ & $\begin{array}{c}4.54 * * * \\
(0.67)\end{array}$ & $\begin{array}{c}2.89 * * * \\
(0.52)\end{array}$ & $\begin{array}{c}-3.90 * * * \\
(0.57) \\
\end{array}$ & $\begin{array}{c}2.21^{* * *} \\
(0.19)\end{array}$ & $\begin{array}{c}-1.668 * * * \\
(0.546) \\
\end{array}$ \\
\hline Unbalanced Panel with trend & $\begin{array}{c}3.09 * * * \\
(0.83) \\
\end{array}$ & $\begin{array}{c}2.66^{* * * *} \\
(0.78) \\
\end{array}$ & $\begin{array}{c}3.52^{* * * *} \\
(0.77)\end{array}$ & $\begin{array}{c}3.07 * * * \\
(0.55) \\
\end{array}$ & $\begin{array}{c}-4.08^{* * *} \\
(0.63) \\
\end{array}$ & $\begin{array}{c}1.83^{* * *} \\
(0.19)\end{array}$ & $\begin{array}{c}-2.246 * * * \\
(0.606) \\
\end{array}$ \\
\hline $\begin{array}{l}\text { Exclude KS from balanced } \\
\text { panel }\end{array}$ & $\begin{array}{l}1.56^{* *} \\
(0.693)\end{array}$ & $\begin{array}{l}1.59 * * \\
(0.634) \\
\end{array}$ & $\begin{array}{l}2.59 * * * \\
(0.591)\end{array}$ & $\begin{array}{l}1.51^{* * *} \\
(0.493) \\
\end{array}$ & $\begin{array}{c}-3.42 * * * \\
(0.563) \\
\end{array}$ & $\begin{array}{l}2.08^{* * *} \\
(0.128)\end{array}$ & $\begin{array}{l}-1.34^{* *} \\
(0.534) \\
\end{array}$ \\
\hline $\begin{array}{l}\text { Exclude KS, OR, SD from } \\
\text { unbalanced panel }\end{array}$ & $\begin{array}{r}3.17 * * * \\
(0.699) \\
\end{array}$ & $\begin{array}{l}3.08^{* * *} \\
(0.692) \\
\end{array}$ & $\begin{array}{l}3.80^{* * *} \\
(0.658) \\
\end{array}$ & $\begin{array}{c}2.93 * * * \\
(0.565) \\
\end{array}$ & $\begin{array}{c}-3.91 * * * \\
(0.566) \\
\end{array}$ & $\begin{array}{l}2.15^{* * *} \\
(0.204) \\
\end{array}$ & $\begin{array}{c}-1.76^{* * *} \\
(0.554) \\
\end{array}$ \\
\hline
\end{tabular}

Notes: Difference-in-differences estimates of the effect of repeal of nonmedical exemptions on childhood vaccination rates and vaccination exemptions. Regressions include county and year fixed effects, county socio-economics time varying characteristics, and rates of vaccine preventable disease cases in the previous year. Standard errors are clustered at the county level. *, **, *** indicates statistical significance at the 10\%, 5\%, and 1\% level. 


\section{Figure 1- Childhood Vaccination Rates and Vaccine Exemption Rates in California}

Panel A: Percentage of Children vaccinated for four major required childhood vaccine, and percentage of children who obtained medical and nonmedical exemptions at the time of Kindergarten entry from 2000-2017 in California. Vertical lines in 2016 indicate the year that California repealed its nonmedical exemptions respectively.

Panel B: Percentage of children exempt from at least one vaccine (medical versus nonmedical) from 2000-2017 in California.

\section{Panel A: Childhood Vaccination Rate}

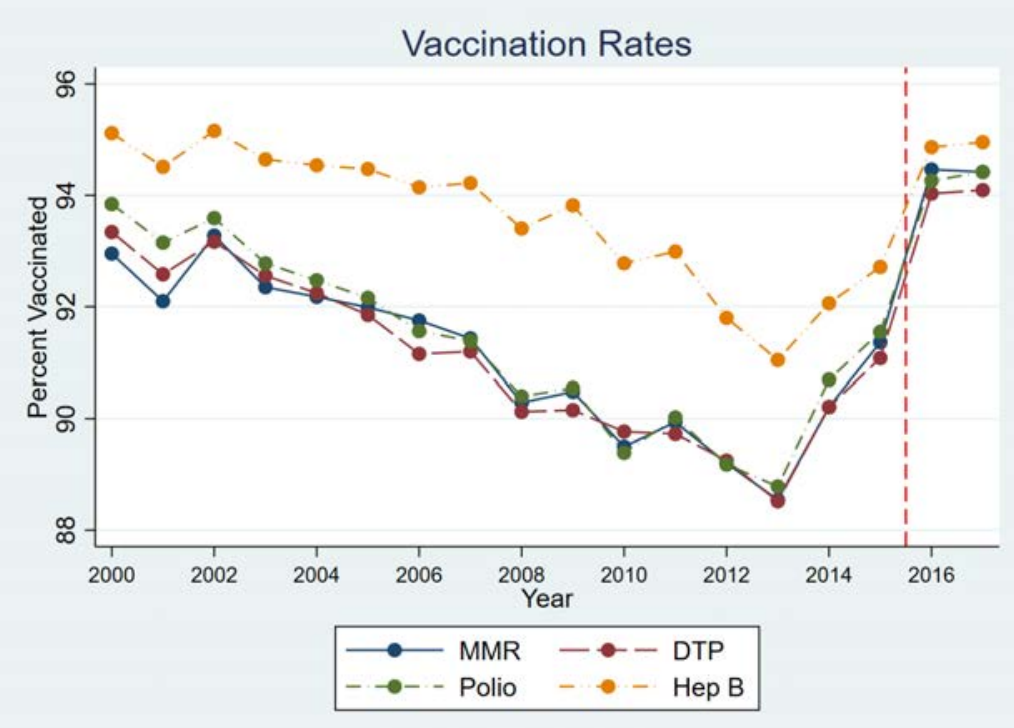

Panel B: Exemption Rates

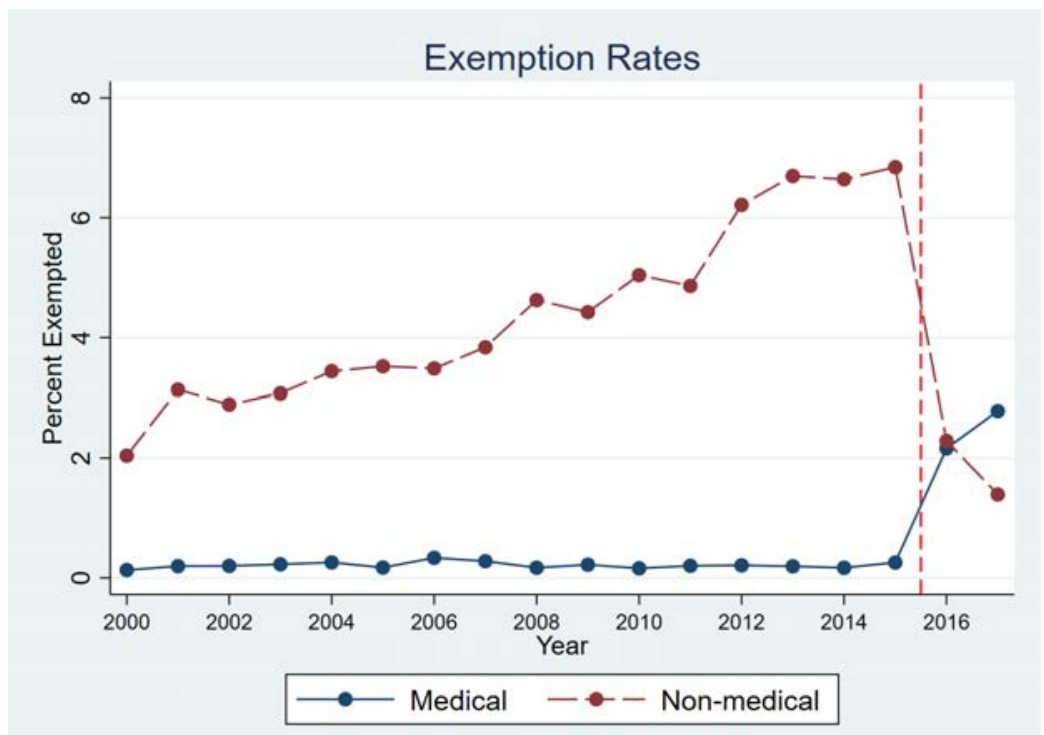




\section{Figure 2- Childhood Vaccination Rates and Vaccine Exemption Rates in California vs. Control States}

Panel A: Percentage of Children vaccinated for four major required childhood vaccine, and percentage of children who obtained medical and nonmedical exemptions at the time of Kindergarten entry from 2012-2017 in California vs control states. Vertical lines in 2016 indicate the year that California repealed its nonmedical exemptions respectively.

Panel B: Percentage of children exempt from at least one vaccine (medical versus nonmedical) from 2012-2017.

\section{Panel A: Childhood Vaccination Rate}
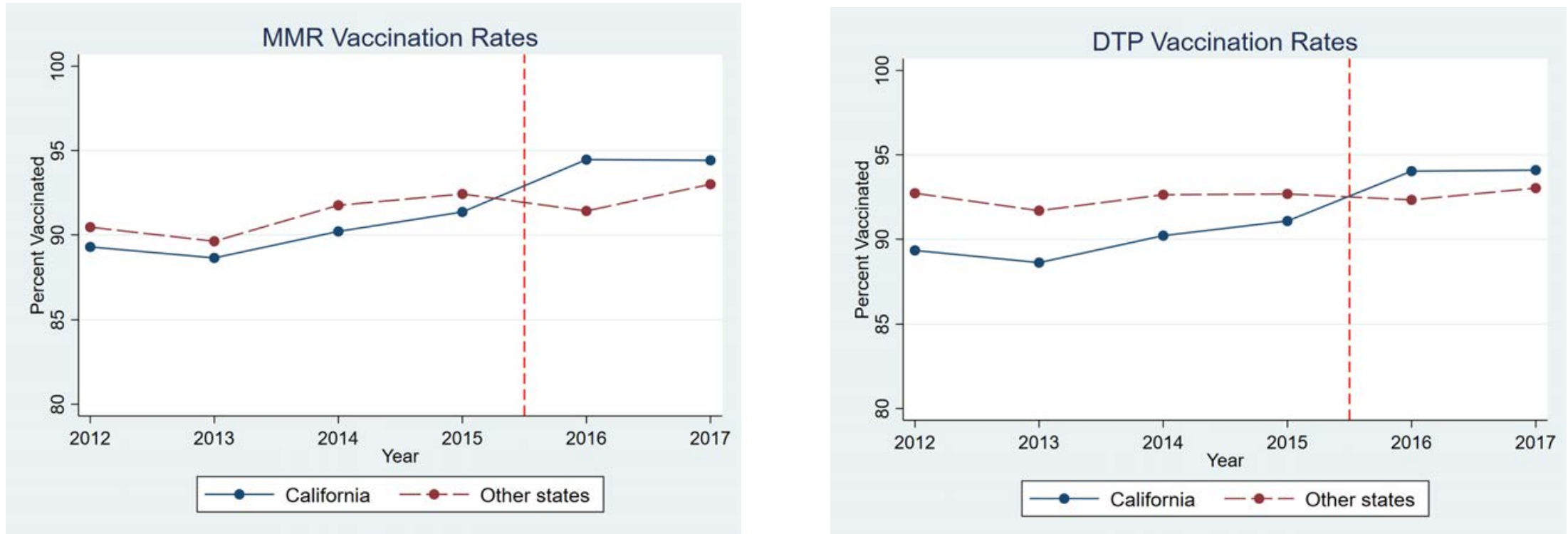

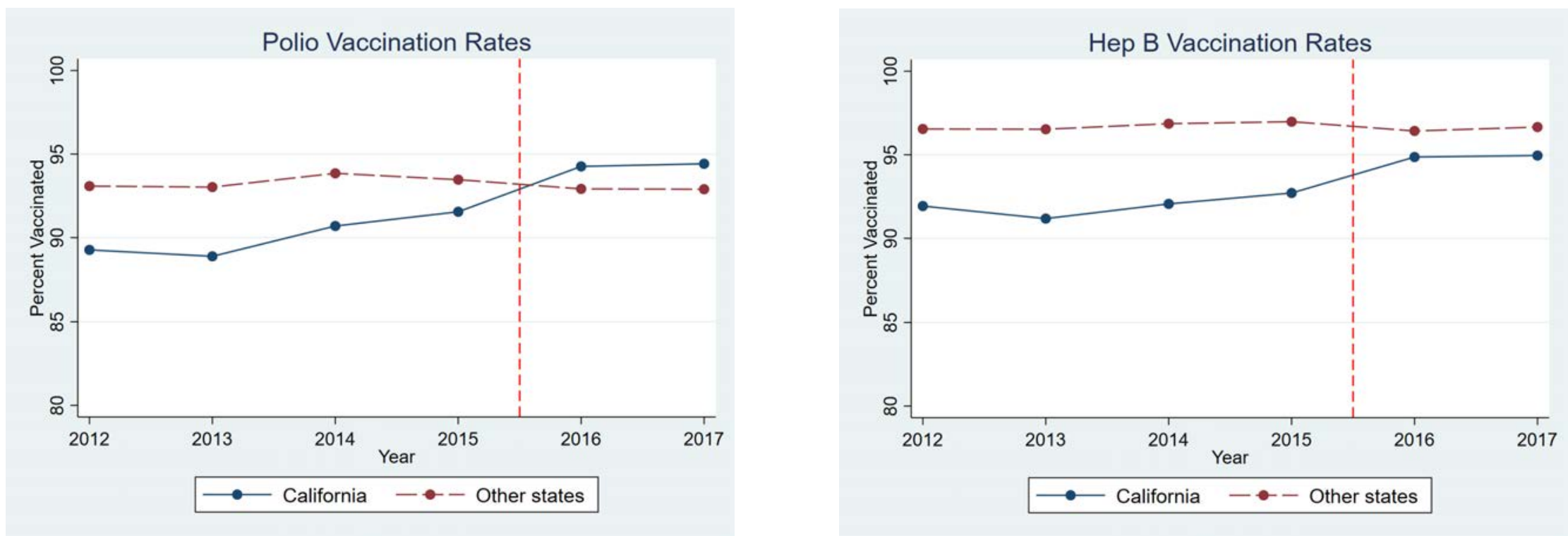


\section{Panel B: Exemption Rates}

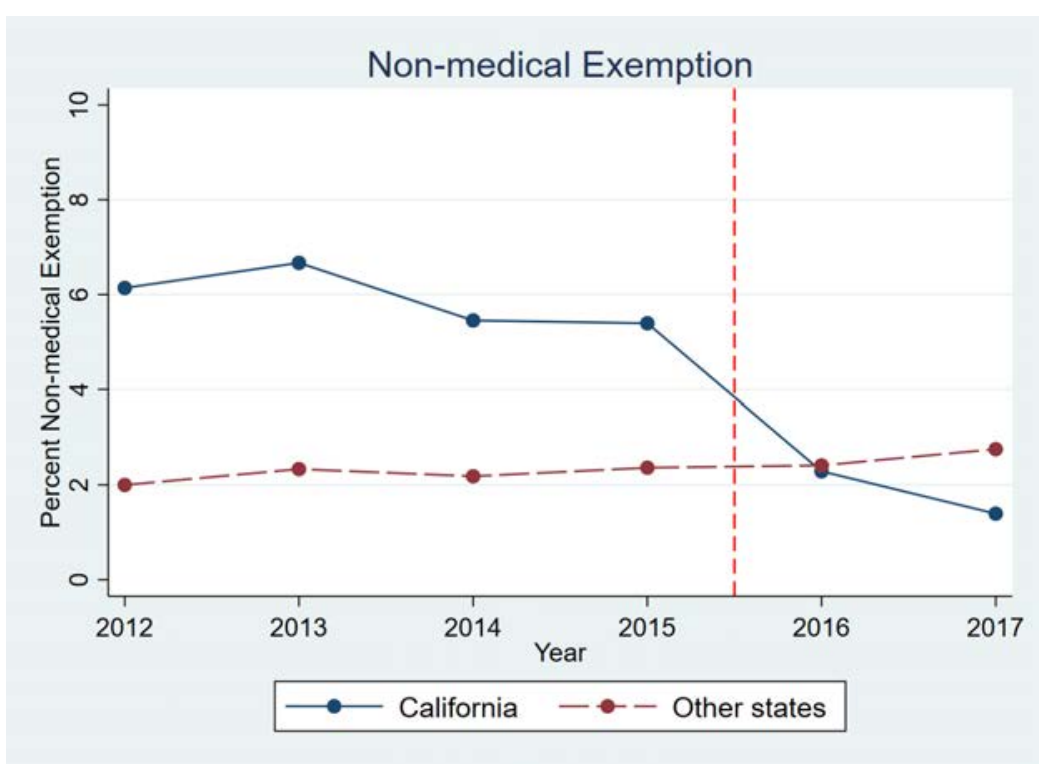

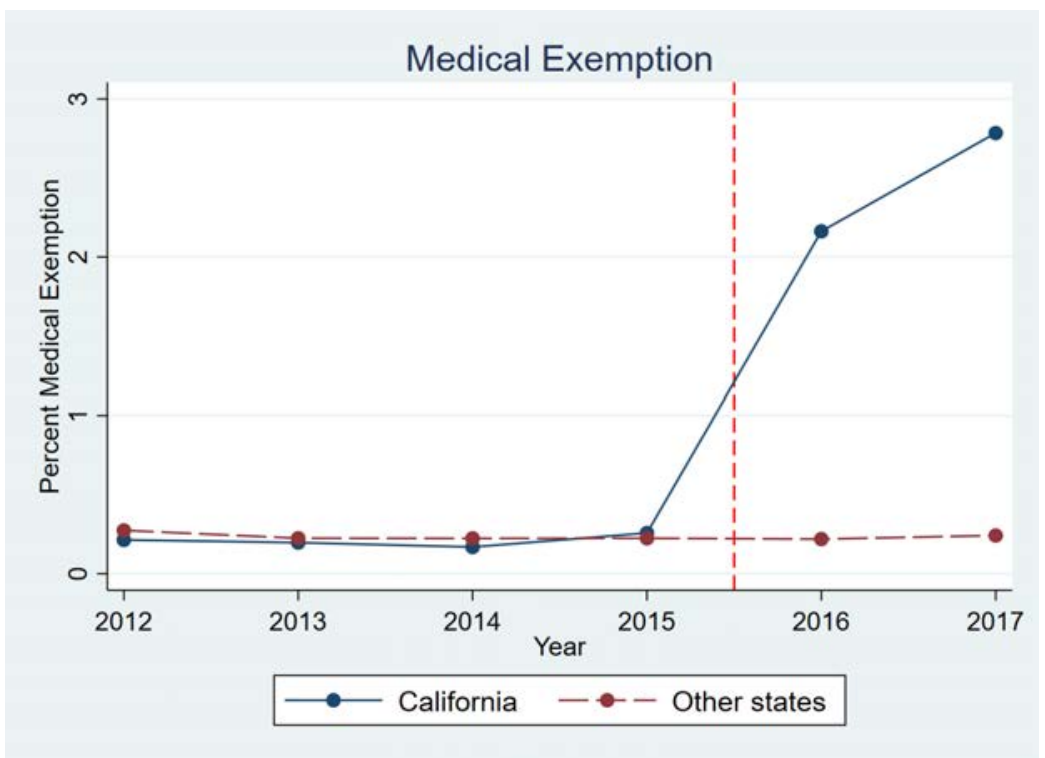


Figure 3- Event Study: Effect of the Repeal of Nonmedical Exemption on Childhood Vaccination Rates and Exemptions- Balanced Panel

Leads and Lags regression of vaccination rates and exemption rates in California, versus all other states in the study (see Table 1) over 2012-2017. Regressions include county and year fixed effects, and socio-economic variables at the county or state level. y-axis shows coefficients on lead and lag dummies; vertical bars show 95\% confidence intervals (CIs) around coefficients, using standard errors clustered on county. Coefficient for year -1 is set to zero.

\section{Panel A- MMR Vaccination}

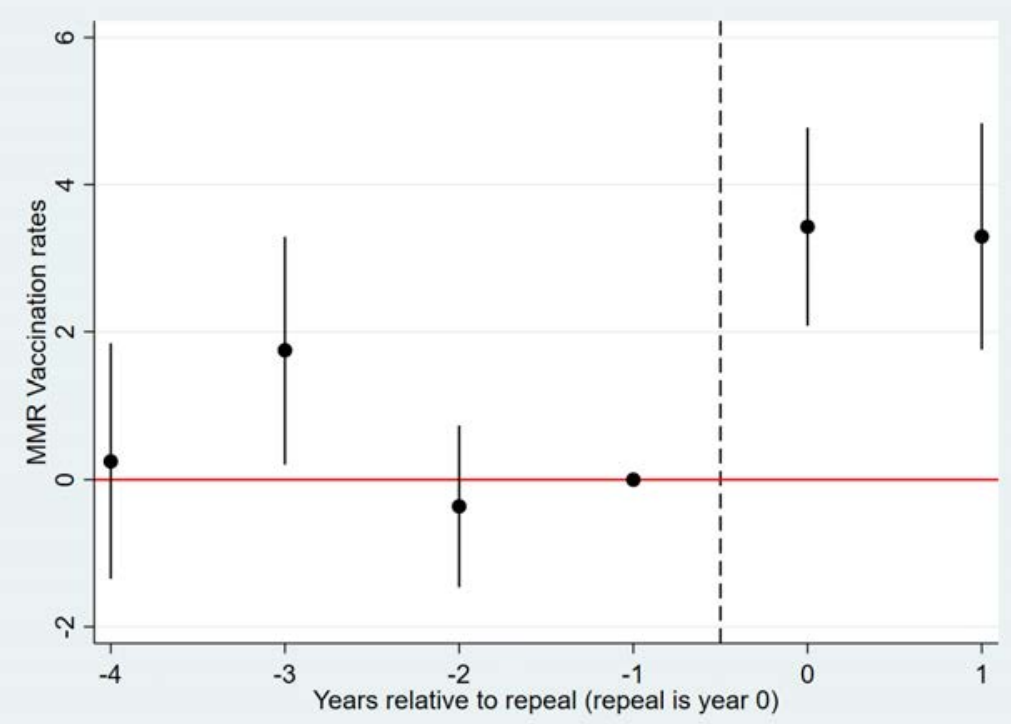

\section{Panel B- DTP Vaccination}

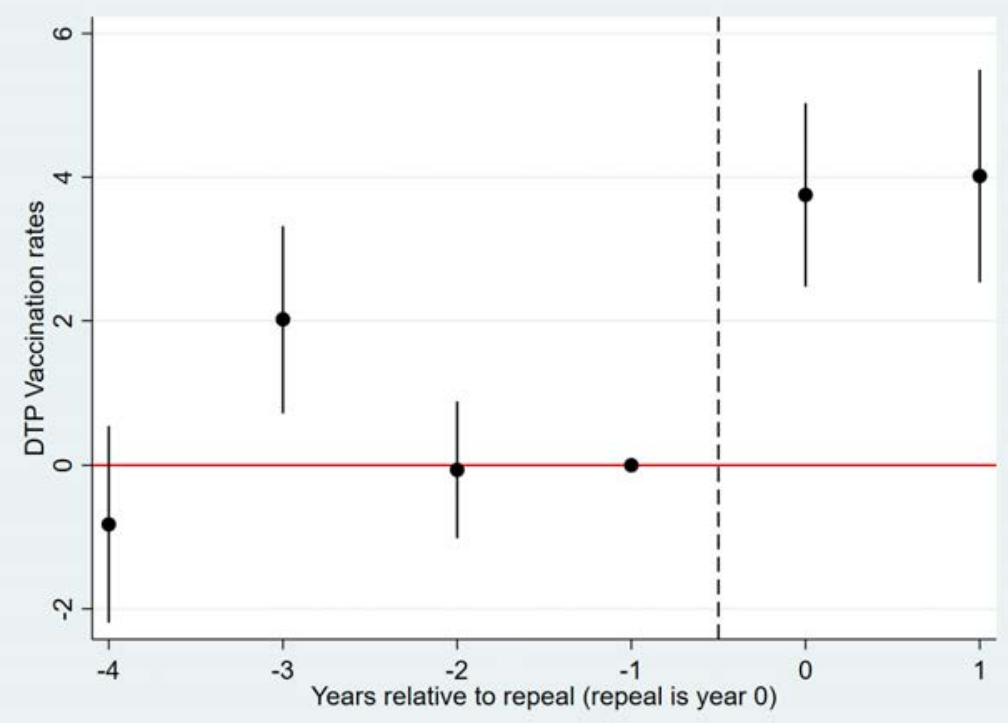




\section{Panel C- Polio Vaccination}

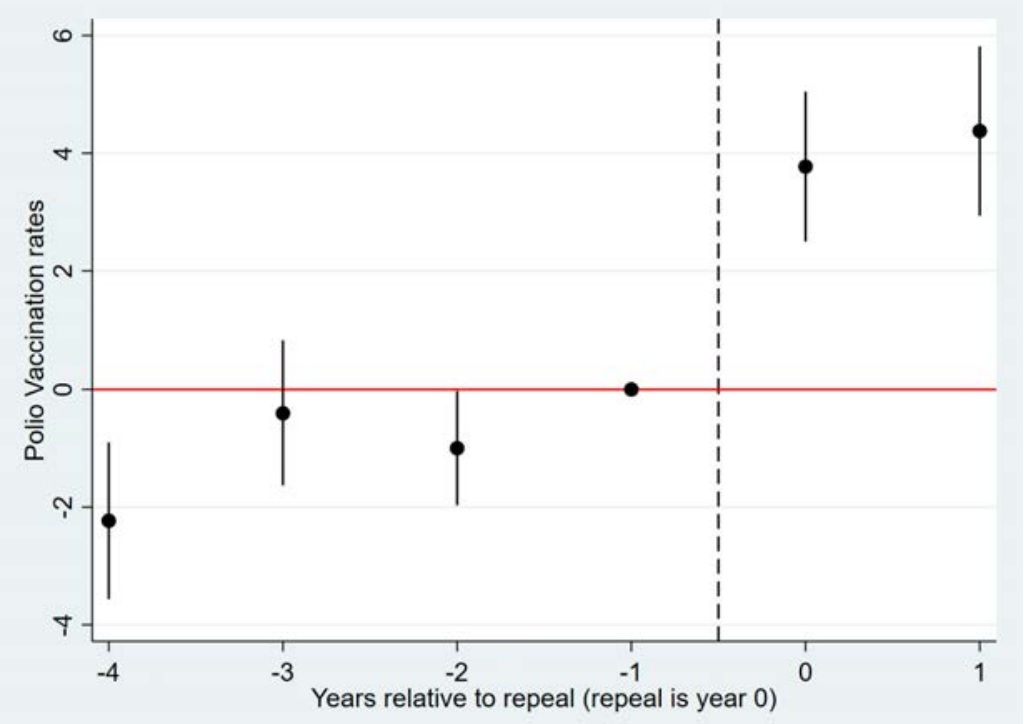

\section{Panel D- Hepatitis B Vaccination}

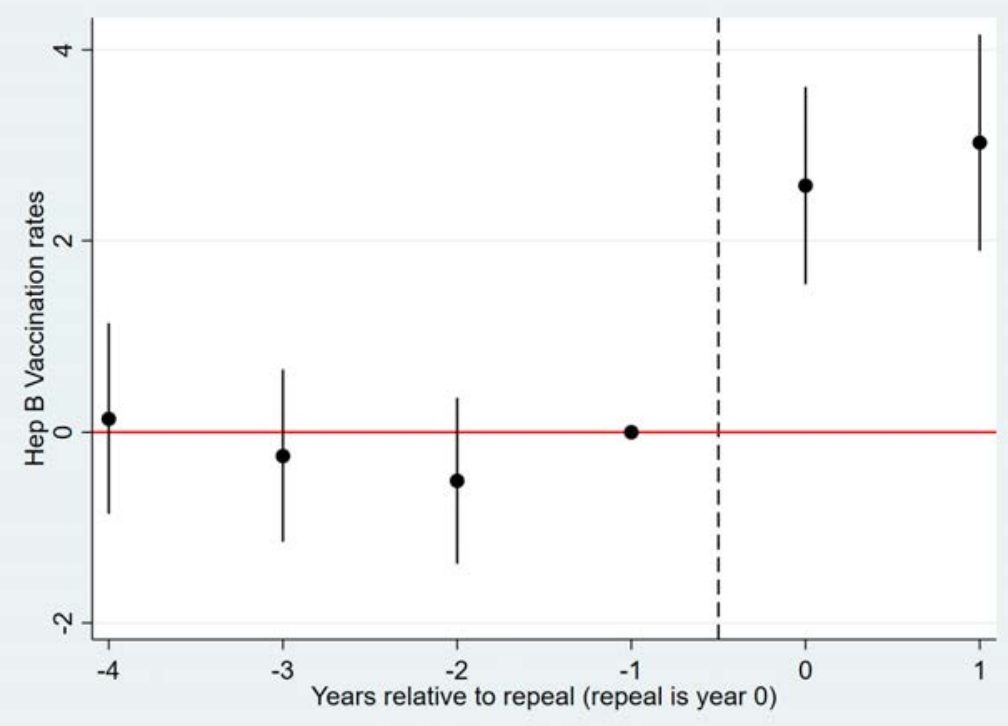




\section{Panel E- Exemptions}

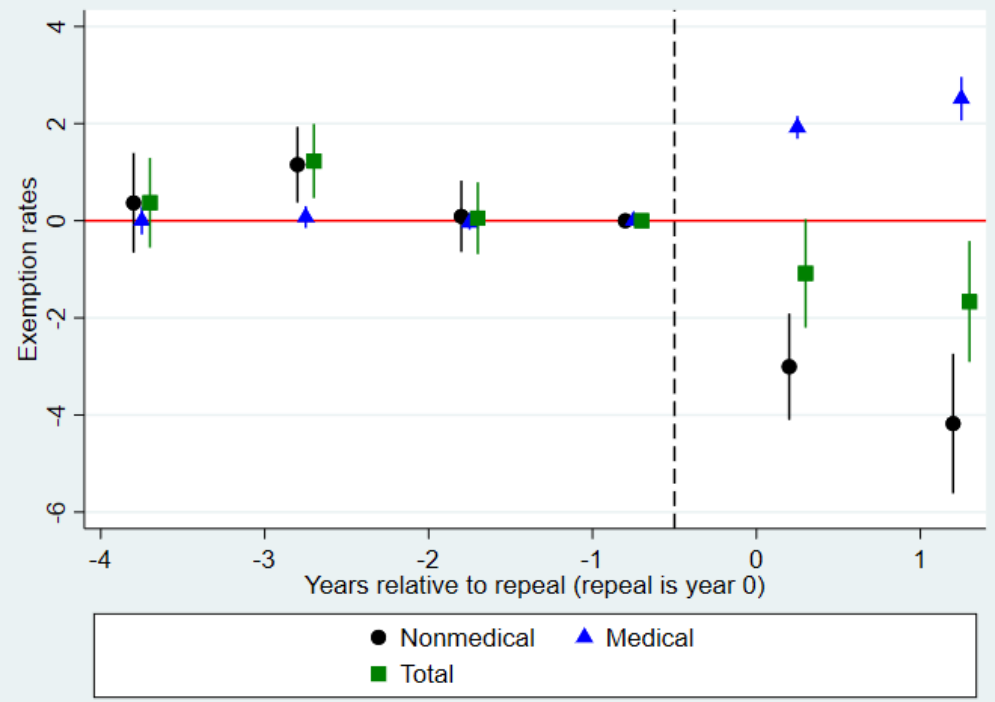


Figure 4- Medical and Nonmedical Exemptions Rates in California, Pre- and Post- Repeal of Nonmedical Exemptions

Panel A- Year 2015
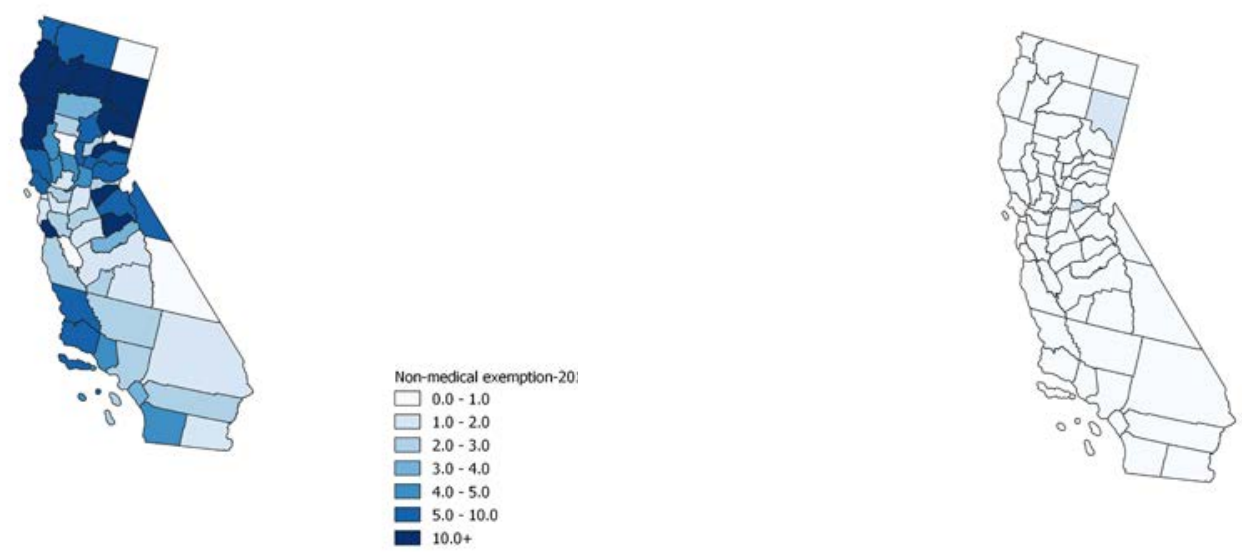

Nonmedical Exemption Rates

Medical Exemption Rates

Panel B- Year 2017
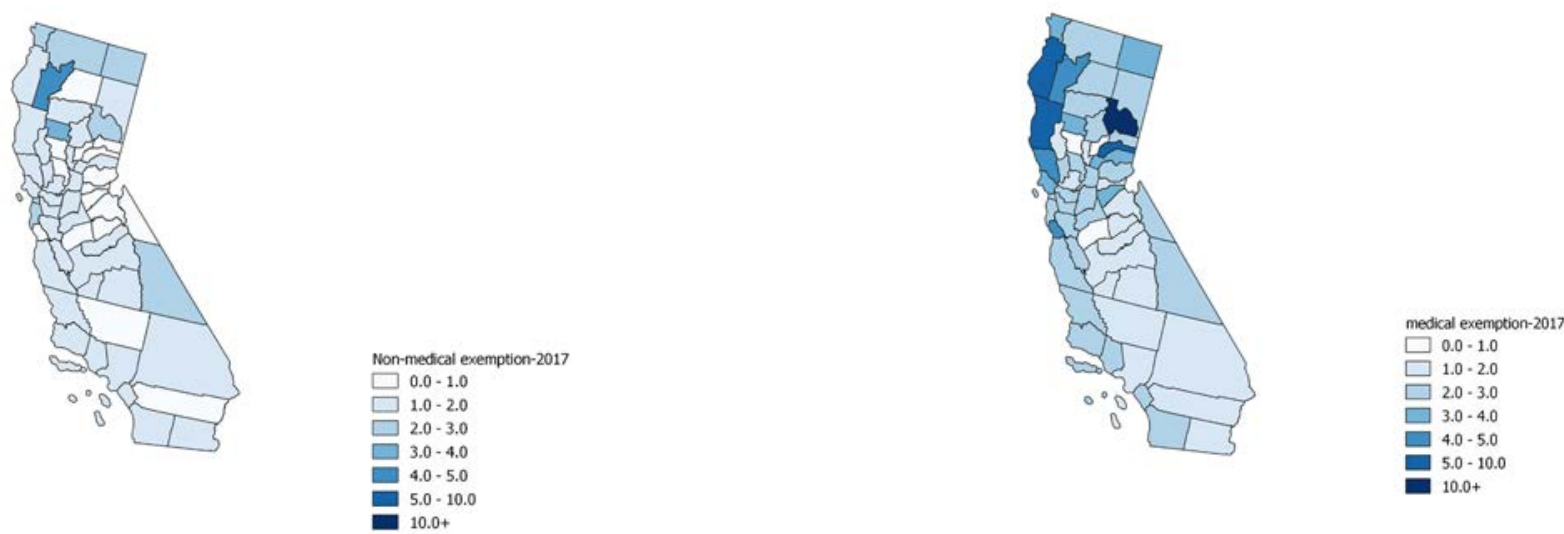

Nonmedical Exemption Rates

Medical Exemption Rate 


\section{Appendix}

\section{1- Additional Graphs and Tables for Results Presented in the Paper}

Table A1 presents the coefficients on covariates from DiD regressions presented in Panel A of Table 3, and Table A2 presents the covariate coefficients from Panel B of Table 3. Figure A1 presents the event analysis from the unbalanced panel. There is some fluctuation in vaccination rates during the pre-treatment period, which is likely noise, followed by a substantial increase in vaccination rates after the repeal of nonmedical exemptions. Nonmedical exemptions were rising from year -7 to -3 , followed by a modest decline in year -2. There was a substantial decline after the repeal of nonmedical exemptions. Medical exemptions were constant during the pre-treatment period, and increased significantly after the repeal.

\section{2- Correlation Coefficients between CDC VPD Incidence and Google Search}

Table A3 presents the Pearson's correlation coefficients between CDC incidence rates and Google search rates. The correlation between the two measures is generally low when we restrict the measure to any specific disease. However, when all the VPDs are lumped together, the correlation coefficients are sizable. 
Table A1: Difference-indifferences: Effect of the Repeal of Nonmedical Exemptions on Childhood Vaccination Rates and Exemptions

\begin{tabular}{|c|c|c|c|c|c|c|c|}
\hline VARIABLES & $\begin{array}{c}(1) \\
\% \text { MMR }\end{array}$ & $\begin{array}{c}\text { (2) } \\
\text { \% DTP }\end{array}$ & $\begin{array}{c}\text { (3) } \\
\text { \% Polio }\end{array}$ & $\begin{array}{c}\text { (4) } \\
\text { \% Hep B }\end{array}$ & $\begin{array}{c}(5) \\
\% \text { Nonmedical } \\
\text { exemptions }\end{array}$ & $\begin{array}{c}6) \\
\text { \% Medical } \\
\text { exemptions }\end{array}$ & $\begin{array}{c}\text { (7) } \\
\% \text { Total } \\
\text { exemptions }\end{array}$ \\
\hline $\begin{array}{l}\text { Repeal of nonmedical } \\
\text { exemptions }\end{array}$ & $\begin{array}{c}2.30^{* * *} \\
(0.86)\end{array}$ & $\begin{array}{c}2.75^{* * * *} \\
(0.77)\end{array}$ & $\begin{array}{c}4.59 * * * \\
(0.76)\end{array}$ & $\begin{array}{c}2.31^{* * *} \\
(0.50)\end{array}$ & $\begin{array}{c}-3.42^{* * *} \\
(0.56)\end{array}$ & $\begin{array}{c}2.08^{* * *} \\
(0.13)\end{array}$ & $\begin{array}{c}-1.34 * * \\
(0.53)\end{array}$ \\
\hline$\%$ pop age 0 to 24 & $\begin{array}{l}-0.85 \\
(0.53)\end{array}$ & $\begin{array}{l}-0.49 \\
(0.48)\end{array}$ & $\begin{array}{l}-0.43 \\
(0.48)\end{array}$ & $\begin{array}{c}0.13 \\
(0.31)\end{array}$ & $\begin{array}{c}0.37 \\
(0.28)\end{array}$ & $\begin{array}{c}-0.19 * * \\
(0.08)\end{array}$ & $\begin{array}{c}0.19 \\
(0.26)\end{array}$ \\
\hline \% pop age 25 to 34 & $\begin{array}{l}1.00 \\
(0.63)\end{array}$ & $\begin{array}{l}1.12^{* *} \\
(0.57)\end{array}$ & $\begin{array}{c}0.91 \\
(0.55)\end{array}$ & $\begin{array}{l}0.91 * * \\
(0.38)\end{array}$ & $\begin{array}{l}0.75 * * \\
(0.37)\end{array}$ & $\begin{array}{c}-0.21^{* *} \\
(0.09)\end{array}$ & $\begin{array}{c}0.54 \\
(0.33)\end{array}$ \\
\hline \% pop age 35 to 44 & $\begin{array}{c}-1.82 * * * \\
(0.68)\end{array}$ & $\begin{array}{l}-1.16^{*} \\
(0.63)\end{array}$ & $\begin{array}{l}-0.48 \\
(0.59)\end{array}$ & $\begin{array}{l}-0.39 \\
(0.31)\end{array}$ & $\begin{array}{c}0.18 \\
(0.30)\end{array}$ & $\begin{array}{c}-0.13^{* *} \\
(0.06)\end{array}$ & $\begin{array}{c}0.05 \\
(0.28)\end{array}$ \\
\hline \% pop age 45 to 54 & $\begin{array}{l}-0.92 \\
(0.62)\end{array}$ & $\begin{array}{l}-0.38 \\
(0.58)\end{array}$ & $\begin{array}{l}-0.57 \\
(0.54)\end{array}$ & $\begin{array}{l}-0.23 \\
(0.32)\end{array}$ & $\begin{array}{c}1.00 * * * \\
(0.35)\end{array}$ & $\begin{array}{l}-0.25^{*} \\
(0.13)\end{array}$ & $\begin{array}{l}0.75 * * \\
(0.34)\end{array}$ \\
\hline \% pop age 55 to 64 & $\begin{array}{l}-1.42^{* *} \\
(0.62)\end{array}$ & $\begin{array}{c}-1.32 * * \\
(0.57)\end{array}$ & $\begin{array}{c}-1.55^{* * *} \\
(0.59)\end{array}$ & $\begin{array}{c}-1.11^{* * *} \\
(0.33)\end{array}$ & $\begin{array}{c}1.58^{* * *} \\
(0.42)\end{array}$ & $\begin{array}{c}-0.40 * * * \\
(0.13)\end{array}$ & $\begin{array}{c}1.18^{* * *} \\
(0.37)\end{array}$ \\
\hline \% pop White & $\begin{array}{c}0.19 \\
(0.35)\end{array}$ & $\begin{array}{c}0.08 \\
(0.31)\end{array}$ & $\begin{array}{l}-0.14 \\
(0.30)\end{array}$ & $\begin{array}{c}0.13 \\
(0.18)\end{array}$ & $\begin{array}{l}0.29 * \\
(0.15)\end{array}$ & $\begin{array}{c}-0.11^{* *} \\
(0.05)\end{array}$ & $\begin{array}{c}0.19 \\
(0.14)\end{array}$ \\
\hline \% pop Black & $\begin{array}{c}0.36 \\
(0.69)\end{array}$ & $\begin{array}{l}-0.46 \\
(0.52)\end{array}$ & $\begin{array}{l}-0.71 \\
(0.50)\end{array}$ & $\begin{array}{l}-0.21 \\
(0.26)\end{array}$ & $\begin{array}{l}-0.44 \\
(0.29)\end{array}$ & $\begin{array}{l}-0.02 \\
(0.08)\end{array}$ & $\begin{array}{l}-0.46^{*} \\
(0.26)\end{array}$ \\
\hline \% pop Hispanic & $\begin{array}{l}-0.42 \\
(0.47)\end{array}$ & $\begin{array}{l}-0.16 \\
(0.44)\end{array}$ & $\begin{array}{l}-0.33 \\
(0.43)\end{array}$ & $\begin{array}{l}-0.40 \\
(0.37)\end{array}$ & $\begin{array}{l}0.37 * \\
(0.21)\end{array}$ & $\begin{array}{c}-0.10^{* *} \\
(0.05)\end{array}$ & $\begin{array}{c}0.26 \\
(0.20)\end{array}$ \\
\hline$\%$ pop Male & $\begin{array}{c}0.58 \\
(0.90)\end{array}$ & $\begin{array}{c}0.32 \\
(0.85)\end{array}$ & $\begin{array}{c}0.12 \\
(0.90)\end{array}$ & $\begin{array}{l}-0.45 \\
(0.41)\end{array}$ & $\begin{array}{c}0.74 \\
(0.47)\end{array}$ & $\begin{array}{c}-0.20^{* *} \\
(0.09)\end{array}$ & $\begin{array}{c}0.54 \\
(0.46)\end{array}$ \\
\hline \% Unemployed & $\begin{array}{c}0.54 * * * \\
(0.20)\end{array}$ & $\begin{array}{c}0.12 \\
(0.18)\end{array}$ & $\begin{array}{c}0.12 \\
(0.18)\end{array}$ & $\begin{array}{c}0.03 \\
(0.12)\end{array}$ & $\begin{array}{c}0.29 * * * \\
(0.09)\end{array}$ & $\begin{array}{c}0.02 \\
(0.02)\end{array}$ & $\begin{array}{c}0.31^{* * * *} \\
(0.09)\end{array}$ \\
\hline Log population & $\begin{array}{c}-36.35 * * * \\
(12.49)\end{array}$ & $\begin{array}{l}-24.89 * * \\
(11.45)\end{array}$ & $\begin{array}{c}-21.30 * * \\
(10.55)\end{array}$ & $\begin{array}{l}-3.92 \\
(8.19)\end{array}$ & $\begin{array}{c}12.42 * * \\
(5.11)\end{array}$ & $\begin{array}{l}-1.08 \\
(1.31)\end{array}$ & $\begin{array}{c}11.33^{* *} \\
(4.78)\end{array}$ \\
\hline Log income per cap & $\begin{array}{c}53.95 * * * \\
(9.33)\end{array}$ & $\begin{array}{c}17.82^{* *} \\
(8.74)\end{array}$ & $\begin{array}{l}-11.04 \\
(9.19)\end{array}$ & $\begin{array}{l}9.73^{*} \\
(5.07)\end{array}$ & $\begin{array}{l}-5.86 \\
(4.16)\end{array}$ & $\begin{array}{c}1.82 \\
(1.27)\end{array}$ & $\begin{array}{l}-4.04 \\
(3.92)\end{array}$ \\
\hline VPD Incidents & $\begin{array}{c}0.02 * * * \\
(0.01)\end{array}$ & $\begin{array}{c}0.06 * * * \\
(0.01)\end{array}$ & $\begin{array}{c}0.05^{* * *} \\
(0.01)\end{array}$ & $\begin{array}{c}0.02 * * * \\
(0.00)\end{array}$ & $\begin{array}{l}-0.00 \\
(0.00)\end{array}$ & $\begin{array}{l}-0.00 \\
(0.00)\end{array}$ & $\begin{array}{l}-0.00 \\
(0.00)\end{array}$ \\
\hline $\begin{array}{l}\text { \% Female with college } \\
\text { degree }\end{array}$ & $\begin{array}{c}0.02 \\
(0.10)\end{array}$ & $\begin{array}{l}-0.04 \\
(0.09)\end{array}$ & $\begin{array}{l}-0.11 \\
(0.09)\end{array}$ & $\begin{array}{c}0.01 \\
(0.05)\end{array}$ & $\begin{array}{l}-0.09 \\
(0.07)\end{array}$ & $\begin{array}{c}0.01 \\
(0.02)\end{array}$ & $\begin{array}{l}-0.08 \\
(0.07)\end{array}$ \\
\hline Constant & $\begin{array}{c}-84.82 \\
(196.19)\end{array}$ & $\begin{array}{c}182.44 \\
(177.92)\end{array}$ & $\begin{array}{c}491.02 * * * \\
(170.14)\end{array}$ & $\begin{array}{c}55.88 \\
(117.21)\end{array}$ & $\begin{array}{l}-196.58^{* *} \\
(85.21)\end{array}$ & $\begin{array}{c}31.97 \\
(24.19)\end{array}$ & $\begin{array}{c}-164.61^{* *} \\
(77.86)\end{array}$ \\
\hline $\begin{array}{l}\text { Observations } \\
\text { R-squared }\end{array}$ & $\begin{array}{c}2,004 \\
0.56\end{array}$ & $\begin{array}{c}2,004 \\
0.58\end{array}$ & $\begin{array}{c}2,004 \\
0.62\end{array}$ & $\begin{array}{c}2,004 \\
0.65\end{array}$ & $\begin{array}{c}1,432 \\
0.77\end{array}$ & $\begin{array}{c}1,432 \\
0.75\end{array}$ & $\begin{array}{c}1,432 \\
0.78\end{array}$ \\
\hline $\begin{array}{l}\text { Notes: Difference-in-di } \\
\text { rates and vaccination ex } \\
\text { varying characteristics, } \\
\text { Standard errors are clus } \\
\text { level. }\end{array}$ & $\begin{array}{l}\text { ences es } \\
\text { iptions. } \\
\text { d number } \\
\text { ed at the }\end{array}$ & $\begin{array}{l}\text { tes of } \\
\text { essions } \\
\text { jaccine } \\
\text { ty lev }\end{array}$ & $\begin{array}{l}\text { effect of } \\
\text { lude co } \\
\text { eventabl } \\
* *, * *\end{array}$ & $\begin{array}{l}\text { al of nc } \\
\text { and yez } \\
\text { ease ca } \\
\text { icates }\end{array}$ & $\begin{array}{l}\text { ical exempt } \\
\text { d effects, co } \\
\text { r } 1,000,000 \\
\text { cal significc }\end{array}$ & $\begin{array}{l}\text { a childhc } \\
\text { ocio-eco } \\
\text { tion in } \mathrm{t} \\
\text { the } 10 \%\end{array}$ & $\begin{array}{l}\text { cination } \\
\text { s time } \\
\text { vious year. } \\
\text { and } 1 \%\end{array}$ \\
\hline
\end{tabular}


Table A2: Difference-in-differences: Effect of Repeal of Nonmedical Exemption on Childhood Vaccination Rates and Exemptions Including State-Specific Time Trends

\begin{tabular}{|c|c|c|c|c|c|c|c|}
\hline VARIABLES & $\begin{array}{c}\text { (1) } \\
\% \text { MMR }\end{array}$ & $\begin{array}{c}(2) \\
\% \text { DTP }\end{array}$ & $\begin{array}{c}(3) \\
\% \text { Polio }\end{array}$ & $\begin{array}{c}\text { (4) } \\
\text { \% Нер B }\end{array}$ & $\begin{array}{c}(5) \\
\% \text { Nonmedical } \\
\text { exemptions }\end{array}$ & $\begin{array}{c}6) \\
\% \text { Medical } \\
\text { exemptions }\end{array}$ & $\begin{array}{c}\text { (7) } \\
\text { \% Total } \\
\text { Exemptions }\end{array}$ \\
\hline $\begin{array}{l}\text { Repeal of nonmedical } \\
\text { exemptions }\end{array}$ & $\begin{array}{c}3.98 * * * \\
(0.79)\end{array}$ & $\begin{array}{c}2.85^{* * * *} \\
(0.77)\end{array}$ & $\begin{array}{c}2.95 * * * \\
(0.75)\end{array}$ & $\begin{array}{c}2.77 * * * \\
(0.52)\end{array}$ & $\begin{array}{c}-3.08 * * * \\
(0.59)\end{array}$ & $\begin{array}{c}2.03 * * * \\
(0.14)\end{array}$ & $\begin{array}{l}-1.05^{*} \\
(0.57)\end{array}$ \\
\hline$\%$ pop age 0 to 24 & $\begin{array}{l}-0.45 \\
(0.56)\end{array}$ & $\begin{array}{l}-0.32 \\
(0.49)\end{array}$ & $\begin{array}{l}-0.51 \\
(0.51)\end{array}$ & $\begin{array}{c}0.17 \\
(0.32)\end{array}$ & $\begin{array}{c}0.40 \\
(0.30)\end{array}$ & $\begin{array}{c}-0.19 * * \\
(0.09)\end{array}$ & $\begin{array}{c}0.21 \\
(0.28)\end{array}$ \\
\hline$\%$ pop age 25 to 34 & $\begin{array}{c}0.06 \\
(0.58)\end{array}$ & $\begin{array}{c}0.21 \\
(0.52)\end{array}$ & $\begin{array}{c}0.42 \\
(0.52)\end{array}$ & $\begin{array}{c}0.52 \\
(0.37)\end{array}$ & $\begin{array}{l}0.72 * \\
(0.39)\end{array}$ & $\begin{array}{c}-0.22 * * \\
(0.09)\end{array}$ & $\begin{array}{c}0.50 \\
(0.35)\end{array}$ \\
\hline \% pop age 35 to 44 & $\begin{array}{l}-0.74 \\
(0.75)\end{array}$ & $\begin{array}{l}-0.71 \\
(0.71)\end{array}$ & $\begin{array}{l}-0.72 \\
(0.66)\end{array}$ & $\begin{array}{l}-0.02 \\
(0.33)\end{array}$ & $\begin{array}{c}0.13 \\
(0.32)\end{array}$ & $\begin{array}{l}-0.09 \\
(0.07)\end{array}$ & $\begin{array}{c}0.04 \\
(0.30)\end{array}$ \\
\hline \% pop age 45 to 54 & $\begin{array}{c}-1.30 * * \\
(0.58)\end{array}$ & $\begin{array}{l}-0.79 \\
(0.55)\end{array}$ & $\begin{array}{l}-0.80 \\
(0.54)\end{array}$ & $\begin{array}{l}-0.42 \\
(0.31)\end{array}$ & $\begin{array}{c}0.98 * * * \\
(0.36)\end{array}$ & $\begin{array}{c}-0.25^{* *} \\
(0.12)\end{array}$ & $\begin{array}{l}0.73 * * \\
(0.35)\end{array}$ \\
\hline \% pop age 55 to 64 & $\begin{array}{l}-1.12^{*} \\
(0.65)\end{array}$ & $\begin{array}{l}-1.02^{*} \\
(0.59)\end{array}$ & $\begin{array}{l}-1.37^{* *} \\
(0.63)\end{array}$ & $\begin{array}{c}-1.11^{* * *} \\
(0.35)\end{array}$ & $\begin{array}{c}1.63 * * * \\
(0.46)\end{array}$ & $\begin{array}{c}-0.41^{* * *} \\
(0.14)\end{array}$ & $\begin{array}{c}1.22 * * * \\
(0.40)\end{array}$ \\
\hline$\%$ pop White & $\begin{array}{l}-0.24 \\
(0.34)\end{array}$ & $\begin{array}{l}-0.20 \\
(0.31)\end{array}$ & $\begin{array}{l}-0.15 \\
(0.30)\end{array}$ & $\begin{array}{l}-0.01 \\
(0.18)\end{array}$ & $\begin{array}{c}0.23 \\
(0.16)\end{array}$ & $\begin{array}{l}-0.10^{*} \\
(0.05)\end{array}$ & $\begin{array}{c}0.14 \\
(0.14)\end{array}$ \\
\hline \% pop Black & $\begin{array}{c}0.37 \\
(0.72)\end{array}$ & $\begin{array}{c}0.28 \\
(0.55)\end{array}$ & $\begin{array}{c}0.35 \\
(0.55)\end{array}$ & $\begin{array}{l}-0.09 \\
(0.25)\end{array}$ & $\begin{array}{l}-0.51 \\
(0.31)\end{array}$ & $\begin{array}{l}-0.01 \\
(0.08)\end{array}$ & $\begin{array}{l}-0.52^{*} \\
(0.28)\end{array}$ \\
\hline \% pop Hispanic & $\begin{array}{l}-0.56 \\
(0.46)\end{array}$ & $\begin{array}{l}-0.44 \\
(0.42)\end{array}$ & $\begin{array}{l}-0.64 \\
(0.45)\end{array}$ & $\begin{array}{l}-0.47 \\
(0.36)\end{array}$ & $\begin{array}{l}0.42 * \\
(0.22)\end{array}$ & $\begin{array}{c}-0.12^{* *} \\
(0.05)\end{array}$ & $\begin{array}{c}0.30 \\
(0.21)\end{array}$ \\
\hline$\%$ pop Male & $\begin{array}{c}0.42 \\
(0.95)\end{array}$ & $\begin{array}{c}0.31 \\
(0.91)\end{array}$ & $\begin{array}{c}0.29 \\
(0.94)\end{array}$ & $\begin{array}{l}-0.56 \\
(0.42)\end{array}$ & $\begin{array}{c}0.71 \\
(0.49)\end{array}$ & $\begin{array}{c}-0.20^{* *} \\
(0.10)\end{array}$ & $\begin{array}{c}0.50 \\
(0.47)\end{array}$ \\
\hline \% Unemployed & $\begin{array}{l}0.44 * \\
(0.26)\end{array}$ & $\begin{array}{c}0.05 \\
(0.22)\end{array}$ & $\begin{array}{c}0.21 \\
(0.23)\end{array}$ & $\begin{array}{l}-0.10 \\
(0.14)\end{array}$ & $\begin{array}{l}0.24 * * \\
(0.11)\end{array}$ & $\begin{array}{c}0.03 \\
(0.03)\end{array}$ & $\begin{array}{l}0.27 * * \\
(0.11)\end{array}$ \\
\hline Log population & $\begin{array}{l}-18.22 \\
(13.45)\end{array}$ & $\begin{array}{c}-1.80 \\
(11.57)\end{array}$ & $\begin{array}{c}-4.81 \\
(10.94)\end{array}$ & $\begin{array}{c}6.62 \\
(8.18)\end{array}$ & $\begin{array}{l}11.99^{* *} \\
(5.35)\end{array}$ & $\begin{array}{l}-0.53 \\
(1.42)\end{array}$ & $\begin{array}{c}11.46 * * \\
(5.03)\end{array}$ \\
\hline Log income per cap & $\begin{array}{c}31.13 \\
(31.94)\end{array}$ & $\begin{array}{c}-3.57 \\
(25.71)\end{array}$ & $\begin{array}{l}-34.23 \\
(26.78)\end{array}$ & $\begin{array}{l}-14.32 \\
(14.99)\end{array}$ & $\begin{array}{c}2.66 \\
(8.27)\end{array}$ & $\begin{array}{c}0.46 \\
(2.29)\end{array}$ & $\begin{array}{c}3.13 \\
(8.29)\end{array}$ \\
\hline VPD Incidents & $\begin{array}{c}0.01 \\
(0.01)\end{array}$ & $\begin{array}{c}0.04 * * * \\
(0.01)\end{array}$ & $\begin{array}{c}0.03 * * * \\
(0.01)\end{array}$ & $\begin{array}{c}0.01^{* * * *} \\
(0.00)\end{array}$ & $\begin{array}{l}-0.00 \\
(0.00)\end{array}$ & $\begin{array}{l}-0.00 \\
(0.00)\end{array}$ & $\begin{array}{l}-0.00 \\
(0.00)\end{array}$ \\
\hline $\begin{array}{l}\% \text { Female with college } \\
\text { degree }\end{array}$ & $\begin{array}{l}-0.08 \\
(0.09)\end{array}$ & $\begin{array}{l}-0.12 \\
(0.09)\end{array}$ & $\begin{array}{l}-0.14 \\
(0.09)\end{array}$ & $\begin{array}{l}-0.03 \\
(0.05)\end{array}$ & $\begin{array}{l}-0.09 \\
(0.07)\end{array}$ & $\begin{array}{c}0.01 \\
(0.02)\end{array}$ & $\begin{array}{l}-0.08 \\
(0.07)\end{array}$ \\
\hline Constant & $\begin{array}{c}7.19 \\
(423.63)\end{array}$ & $\begin{array}{c}201.00 \\
(307.89)\end{array}$ & $\begin{array}{l}572.80^{*} \\
(309.76)\end{array}$ & $\begin{array}{c}226.24 \\
(192.53)\end{array}$ & $\begin{array}{c}-277.64 * * \\
(118.73)\end{array}$ & $\begin{array}{c}39.66 \\
(33.94)\end{array}$ & $\begin{array}{c}-237.98 * * \\
(114.32)\end{array}$ \\
\hline Observations & 2,004 & 2,004 & 2,004 & 2,004 & 1,432 & 1,432 & 1,432 \\
\hline R-squared & 0.58 & 0.60 & 0.63 & 0.67 & 0.77 & 0.75 & 0.78 \\
\hline
\end{tabular}


Table A3: Pearson's Correlation Coefficients for CDC Incident Rate and Google Trends Search Rate Measures

\begin{tabular}{llc}
\hline Google Search Rate Variables & CDC Incident Rate Variables & Correlation Coefficient \\
DtaP/DTP Searches & DTP Incidents (sum) & -0.07 \\
& Tetanus Incidents & 0.17 \\
& Pertussis Incidents & -0.07 \\
MMR Searches & MMR Incidents (sum) & 0.04 \\
& Mumps Incidents & 0.04 \\
Hep B Searches & Rubella Incidents & -0.32 \\
VPD Searches (sum) & Hep B Incidents & 0.21 \\
\hline
\end{tabular}

Note: Weekly data is not available for diphtheria or measles incidents due to low frequency. 
Figure A1- Event Study: Effect of the Repeal of Nonmedical Exemption on Childhood Vaccination Rates and Exemptions- Unbalanced Panel

Leads and Lags regression of vaccination rates and exemption rates in California, versus all other states in the study (see Table 1) over 2008-2017. Regressions include county and year fixed effects, and socio-economic variables at the county or state level. y-axis shows coefficients on lead and lag dummies; vertical bars show 95\% confidence intervals (CIs) around coefficients, using standard errors clustered on county. Coefficient for year -1 is set to zero.

\section{Panel A- MMR Vaccination}

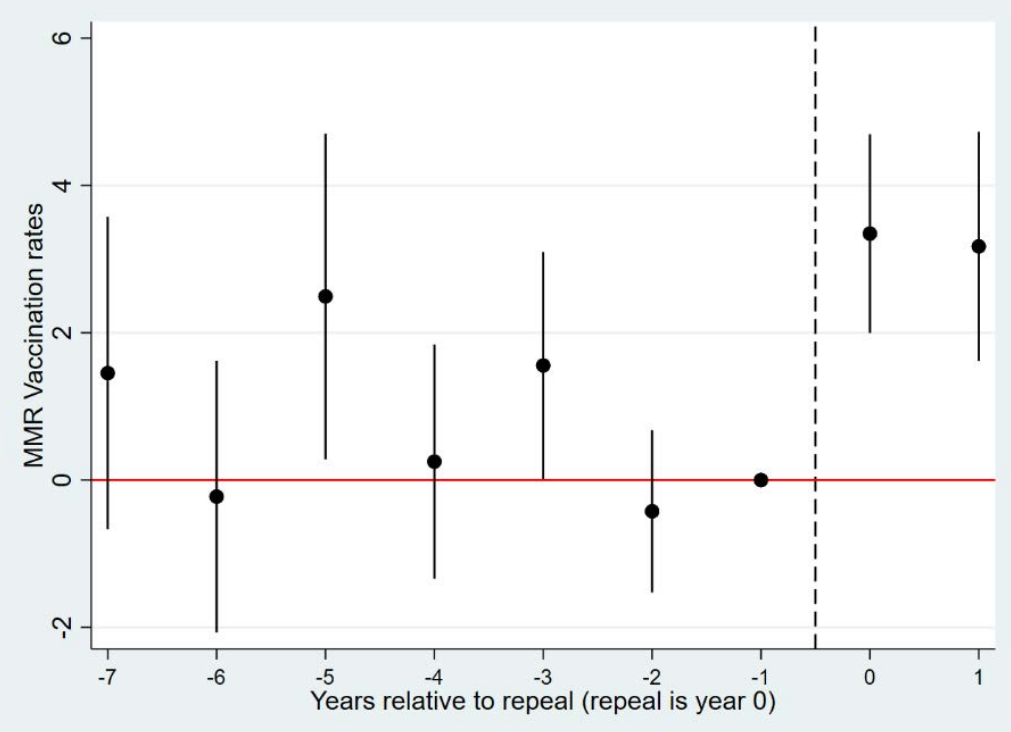

Panel B- DTP Vaccination

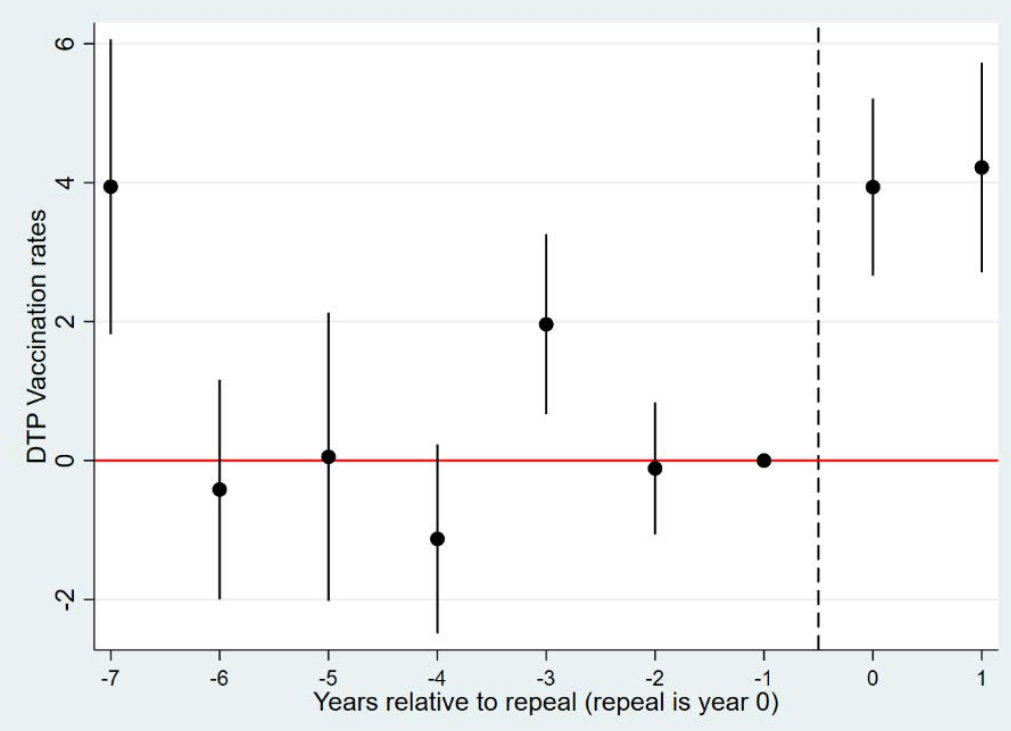




\section{Panel C- Polio Vaccination}

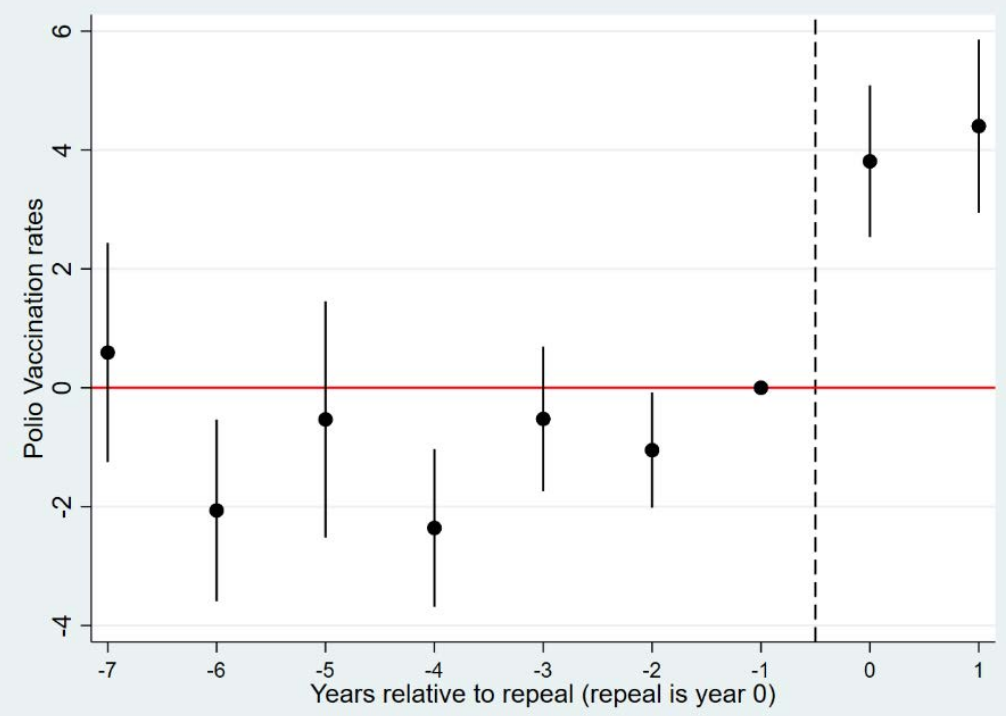

\section{Panel D- Hepatitis B Vaccination}

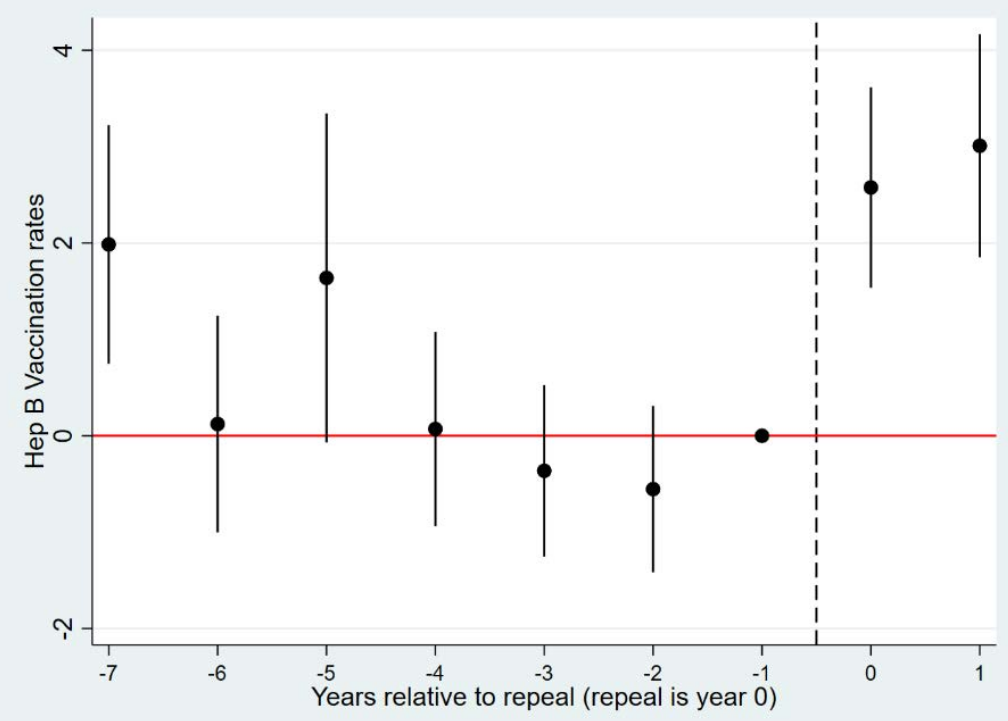




\section{Panel E- Exemptions}

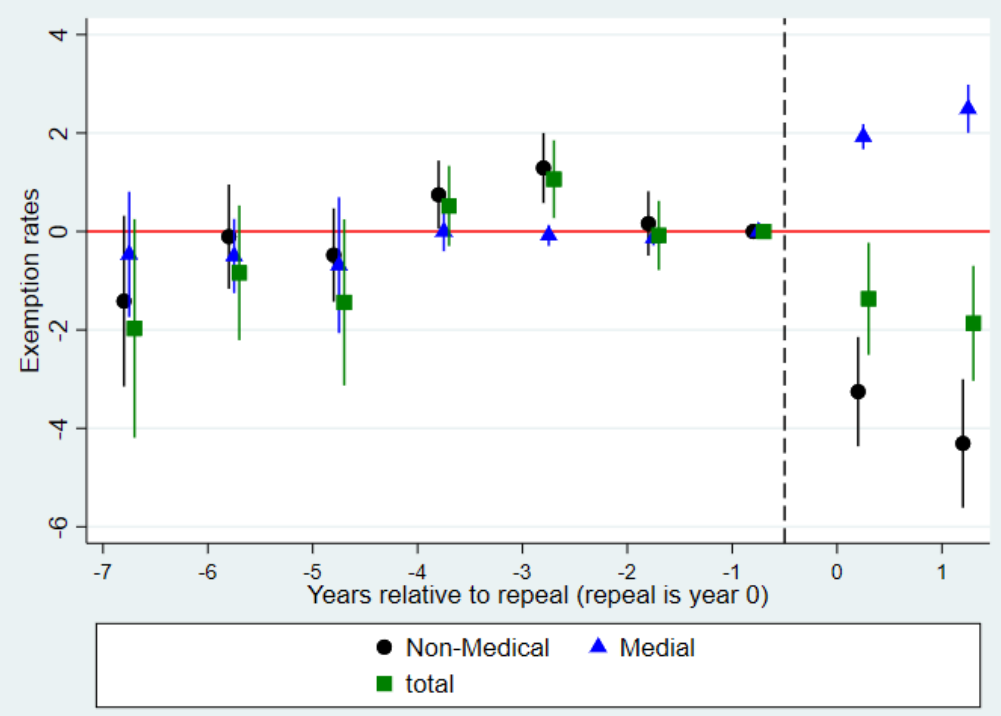

